\title{
Consumer Health Information Technology in the Prevention of Substance Abuse: Scoping Review
}

Apoorva Milind Pradhan ${ }^{1 *}$, BAMS, MPH; Leah Park ${ }^{1 *}$, MS, PharmD; Fadia T Shaya ${ }^{1 *}$, MPH, PhD; Joseph Finkelstein ${ }^{2^{*}}$, $\mathrm{MD}, \mathrm{PhD}$

\footnotetext{
${ }^{1}$ Department of Health Services Research, University of Maryland School of Pharmacy, Baltimore, MD, United States

${ }^{2}$ Icahn School of Medicine at Mount Sinai, New York, NY, United States

*all authors contributed equally
}

\section{Corresponding Author:}

Fadia T Shaya, MPH, PhD

Department of Health Services Research

University of Maryland School of Pharmacy

220 Arch Street, 12th Floor, 01-204

Baltimore, MD, 21201

United States

Phone: 14107065392

Email: fshaya@rx.umaryland.edu

\begin{abstract}
Background: Addiction is one of the most rapidly growing epidemics that currently plagues nations around the world. In the United States, it has cost the government more than US \$700 billion a year in terms of health care and other associated costs and is also associated with serious social, physical, and mental consequences. Increasing efforts have been made to tackle this issue at different levels, from primary prevention to rehabilitation across the globe. With the use of digital technology rapidly increasing, an effort to leverage the consumer health information technologies (CHITs) to combat the rising substance abuse epidemic has been underway. CHITs are identified as patient-focused technological platforms aimed to improve patient engagement in health care and aid them in navigating the complex health care system.
\end{abstract}

Objective: This review aimed to provide a holistic and overarching view of the breadth of research on primary prevention of substance abuse using CHIT conducted over nearly past five decades. It also aimed to map out the changing landscape of CHIT over this period.

Methods: We conducted a scoping review using the Arksey and O'Malley's modified methodological framework. We searched 4 electronic databases (PubMed, Cochrane, Scopus, and EMBASE). Papers were included if the studies addressed the use of CHIT for primary prevention of substance abuse and were published in English between 1809 and 2018. Studies that did not focus solely on primary prevention or assessed additional comorbid conditions were eliminated.

Results: Forty-two papers that met our inclusion criteria were included in the review. These studies were published between 1970 and 2018 and were not restricted by geography, age, race, or sex. The review mapped studies using the most commonly used CHIT platforms for substance abuse prevention from mass media in the 1970s to mobile and social media in 2018. Moreover, 191 studies that were exclusively focused on alcohol prevention were excluded and will be addressed in a separate paper. The studies included had diverse research designs although the majority were randomized controlled trials (RCT) or review papers. Many of the RCTs used interventions based on different behavioral theories such as family interactions, social cognitive theories, and harm-minimization framework.

Conclusions: This review found CHIT platforms to be efficacious and cost-effective in the real-world settings. We also observed a gradual shift in the types and use of CHIT platforms over the past few decades and mapped out their progression. In addition, the review detected a shift in consumer preferences and behaviors from face-to-face interactions to technology-based platforms. However, the studies included in this review only focused on the aspect of primary prevention. Future reviews could assess the effectiveness of platforms for secondary prevention and for prevention of substance abuse among comorbid populations.

(J Med Internet Res 2019;21(1):e11297) doi: $\underline{10.2196 / 11297}$ 


\section{KEYWORDS}

consumer health information technology; primary prevention; substance abuse; review

\section{Introduction}

\section{Background}

Addiction has been identified as the most neglected disease in the United States, with nearly 40 million Americans over the age of 12 years meeting the clinical criteria for addiction involving nicotine, alcohol, or other drugs [1]. In addition, it is also estimated that nearly 80 million people in the country are risky substance users, meaning that although they are not addicted, they use tobacco, alcohol, and other drugs in ways that could be harmful and threaten public health and safety [1]. Thus, addiction has been established as a growing epidemic. In 2017, the American government spent in excess of US \$740 billion in costs related to crime, lost work, and health care, and costs are growing exponentially [2-6].

However, the burden of drug and alcohol use and abuse is not just limited to the United States. The World Health Organization (WHO) estimates the global burden of disease related to drug and alcohol abuse to be nearly $5.4 \%$ [3]. Drug use is associated with grave long-term and short-term health implications and is recognized as one of the avoidable causes of mortality [7]. According to the National Institute on Drug Abuse, in the United States, nearly 64,070 people died of drug overdose in 2016, and this number is rapidly increasing [8]. Given the dire medical, social, and economic consequences associated with increasing drug use, the governments and institutions around the world have been working tirelessly to develop strategies to combat this drug epidemic.

Among the many interventions developed to address the drug epidemic, prevention strategies have shown to be effective to reduce the onset of drug use and risk of drug abuse [9]. Prevention in the field of addiction and substance abuse may be classified as primary, secondary, and tertiary [10]. Primary prevention could be defined as efforts to improve health and forestall the onset of substance abuse and delay the first use (WHO). Primary prevention can be targeted toward the general population, individuals who are at risk of substance abuse, or those who have signs indicating predisposition to developing addiction [11]. As substance abuse can lead to other medical and social problems and have a negative impact not only on individuals, their families, and the society (Substance Abuse and Mental Health Services Administration), effective primary prevention strategies can have beneficial cascading effects in the long run [12].

Among the various strategies implemented for prevention, consumer health information technology (CHIT) has emerged as a potentially effective way to prevent and treat substance abuse [13]. CHIT has been defined in several ways [14-18]. For the purpose of our review, we decided to adopt a combination of 2 definitions of CHIT by Or et al and Tao et al to broaden our scope of work $[14,17,18]$. Or et al have defined CHIT as "patient-focused interactive web- or technology-mediated applications that are designed to improve information access and exchange, enhance decision making, provide social and emotional support, and facilitate behavior changes that promote health and wellbeing" $[14,18]$, whereas Tao et al have defined it as "consumer-centered electronic tools, technologies, apps, or systems that are interacted with directly by health consumers to provide them with data, information, recommendations, or services for promotion of health and health care" [17]. CHIT has experienced an exponential growth during the recent decades [13]. The traditional CHIT platforms for health promotion such as educational audio and video materials, along with the rapid proliferation of new modalities, take advantage of the wide accessibility of health-related content via internet, mobile phones, and social media [19]. By 2016, nearly $88 \%$ Americans were using the internet [20], 92\% a cell phone, and $76 \%$ social media [21]. Given the reach of these modalities, technologies such as the internet and mobile phones are viewed as a promising platform for affecting assessment, prevention, treatment, and recovery of substance abuse disorders by national and global organizations [22].

In the past few decades, multiple research studies have been conducted on the use of CHIT in the prevention of substance abuse, but the reflective step of looking broadly across this vast research corpus is yet to be undertaken. Previous reviews on CHIT and substance abuse have assessed the impact of CHIT with narrow focuses in terms of targeted study populations and specific types of technology [23-25]. Moreover, 1 systematic review evaluated benefits, potentials, and shortcomings of recent technology such as social media and mobile apps as an intervention for substance use among those who also have HIV. This study concluded the new technology is well accepted and has good feasibility with great potential for educating people on sensitive topics [25]. Another study investigated the benefits of technology on prevention and treatment of substance use among young people and reported that technology is particularly effective in both prevention and treatment regardless of the stage of substance abuse [23]. Moore et al reported that the use of computers in the prevention of drug abuse was effective in reducing substance use and improving knowledge, leading to greater motivation to change behavior and was well accepted by users [24].

Although these reviews presented the impact of CHIT on substance abuse from various perspectives, there has not been a comprehensive review of how interventions using CHIT have shaped primary prevention of substance abuse over the years. Furthermore, some of the previous reviews were limited to studies that used technologies used in recent decades [23,25]. Before the advent of mobile phones and internet, other types of technologies, including phone, television, radios, and videos, played a prominent role in prevention of substance abuse [26-30]. Although some of these technologies from the previous decades are no longer in widespread use, there are valuable lessons that can be learned from which past strategies using technology-based interventions were effective or ineffective and how technology has evolved over the years. Due to the lack of studies that provided overall assessment of effectiveness of CHIT on primary prevention of substance abuse, we focused 
the scope of our review on primary prevention of various types of substance abuse and identified studies that provided prevention efforts to reduce the new onset of substance abuse.

\section{Objective}

In this study, we present a scoping review of the breadth of research over the past few decades, specifically with the use of CHIT in the primary prevention of substance abuse. The objective of this review was to describe the use of CHIT in the primary prevention of substance abuse over the last five decades and examine the changes and developments in the types of CHIT employed for this effort. Our goal was also to summarize these preventive approaches and report lessons learned from these studies.

\section{Methods}

After considering the multiple systematic approaches that are used for the review of published literature, we decided to undertake a scoping review to map out the changing trends in the use of CHIT in the substance abuse prevention landscape over the past few decades. The scoping review methodology is more commonly known as mapping, a process of summarizing the range of evidence to convey the depth and the breadth of the published literature in a particular field of interest. Unlike systematic reviews and meta-analysis, scoping reviews are neither limited by the type of study under consideration nor do they evaluate their quality. Yet, it enables the researcher to examine the extent, range, and nature of research activity; determine whether a full systematic review would be of value; summarize and disseminate the research findings; and identify gaps in the literature [31-34].

In designing our scoping review, we used Arksey and O'Malley's pioneering framework and incorporated recent scoping review publications as well. Arksey and O'Malley's scoping review framework outlines a 5-stage approach, which was further adapted and modified to some extent by others to develop a more feasible approach for reviewing such a vast body of literature [31,32]. The 5 steps are each discussed below.

\section{Identifying the Research Questions}

The growing drug abuse epidemic in the United States underscores the need for exploring new approaches to prevention. The ubiquitous nature of CHIT in our day-to-day lives presents an opportunity to study its potential as a tool for substance abuse prevention. Our intent, thus, was to learn the extent of the present use of CHIT platforms in substance abuse prevention; however, the scope of this review was only limited to primary prevention, and not secondary prevention. In addition, we intended to explore the best methods to leverage CHIT platforms in the future among high-risk individuals for primary prevention. Our goal was to examine the following: (1) extent, range, and nature of the evidence; (2) identify gaps in the literature; and (3) summarize and disseminate this information to guide practice and policy. Following Levac et al's suggestion to enhance and advance Arksey and O'Malley framework, our team clarified and linked the purpose and the research question from the beginning of this study. To avoid leading with a highly focused research question, we asked a sufficiently broad question: what is the role and scope of CHIT in the primary prevention of substance abuse? [31,32]. To further guide our review, we formulated 4 subquestions:

1. What are the demographics related to substance abuse disorder studied?

- Locations — study site - the United States, the United Kingdom, and multicountry

- Demographics of the study population and sample size of the study

- Length of observation-long-term impact versus short-term impact

2. What is the type of intervention and the behavioral framework, if any, used?

- Intervention-primary prevention

- Behavioral framework-transtheoretical model, motivational interviewing, brief intervention, acceptance and commitment therapy, and psychoeducation

3. What is the type of CHIT used?

- CHIT-desktop, tablet, mobile phone, internet, interactive voice response, video or movies, video recording or audio recording, and radio

- Social media-Baidu Tieba, Facebook (and its associated Facebook Messenger), Gab, Google+, Myspace, Instagram, LinkedIn, Pinterest, Tumblr, Twitter, Viber, VK, WeChat, Weibo, WhatsApp, Wikia, Snapchat, and YouTube

4. What are the major takeaways from the literature in terms of outcomes and is the intervention effectiveness evident within the literature?

- Outcomes-change in knowledge, attitudes, and behaviors

- Effectiveness - intervention outcomes presented by the author(s) and their suggestions for future research

\section{Identifying Relevant Studies}

Arksey and O'Malley in their study had emphasized the need to be comprehensive while conducting a scoping review [31]. At this stage, our team deliberated and decided on the various search terms, databases, search strategies, and eligibility criteria. To maintain a broad approach, we did not limit the inclusion of studies by the type of substance used. With the aid of a librarian, we searched electronic databases such as PubMed, Scopus, EMBASE, and the Cochrane library. Various search terms and their combinations were used to identify relevant studies, which discussed the use of CHIT in substance abuse prevention: "technology, internet, cell phone, multimedia, computer-assisted, telemedicine, social media, internet, web-based, etc. with prevention and control, preventive health services and substance-related disorders, substance abuse, substance misuse, drug addiction." An exhaustive list of the search terms used can be found in the Multimedia Appendix 1.

\section{Eligibility Criteria}

The following inclusion criteria were used to guide the search and were also used for reviewing papers: 
- Publication language-English

- Only limited to human subjects

- $\quad$ Time range-from 1809 to January 2018

- All age groups

- Review papers included-research studies, systematic reviews, meta-analysis, narrative reviews, observational studies, randomized control trials (RCT), qualitative studies, completed clinical trials, and dissertations and working papers

- Reviews, including but not limited to developed countries, given the growing drug abuse presence all around the world. Studies were included from the United States, the United Kingdom, Canada, Europe, Middle East, South America, Southeast Asia, New Zealand, and Australia

- Studies that address the role of CHIT in primary prevention of only substance abuse-defined as strategies to prevent initiation of substance abuse

Exclusion criteria are as follows:

- Journal papers that are not research studies or reviews (ie, those besides the ones defined in the inclusion list) such as editorial reviews, commentaries, opinion papers, and book reviews

- Research targeting secondary prevention strategies such as treatment, maintenance, relapse, and interventions

- Research studies that lacked the use of CHIT as a part of their interventions for primary prevention

- Research studies aimed at prevention of substance abuse among individuals with comorbidities such as HIV and risky health behaviors

- Research studies conducted in special populations such as cancer patients and patients with HIV, AIDS, or other sexually transmitted diseases (STDs)

\section{Results}

\section{Study Selection}

The literature search yielded 4393 papers. Following the search, the study selection was conducted in 2 parts. First, a single reviewer conducted a title screening process based on the inclusion and exclusion criteria. At this stage of screening, any ambiguity after reviewing the title, with regard to the context of the study, did not eliminate it from being considered for the next step. After completion of this step, 1606 papers were identified; then based on the eligibility criteria, 2 reviewers independently conducted abstract coding. On completion of abstract coding, the inclusion of the paper for full-text review was determined by corroboration from both the reviewers. Given the objective of this review, we wanted to assess the overall breadth of the literature on alcohol; thus, our initial yield for all studies included alcohol whether with or without other substances. On the initial screen, we only kept those studies that considered alcohol along with other substances to make sure that we address the impact of CHIT in prevention of all types of substance abuse without our conclusions being skewed because of any single substance of abuse. We think that it is important to note that about $79.2 \%(191 / 241)$ of all the overall CHIT literature on substance use addressed only alcohol, whereas $20.7 \%(50 / 241)$ addressed other substances with or without alcohol. Our intent was to include studies addressing alcohol to the extent that they also addressed the concurrent use of other substance. Given the epidemiology and suggestive evidence of alcohol being a gateway to other drugs, we decided to separately synthesize the studies focused singularly on alcohol in an independent review altogether. Hence, for the purpose of this review, papers focusing solely on alcohol abuse prevention were excluded. We only included studies that focused solely on substance abuse prevention. Studies that looked at substance abuse prevention in conjunction with other morbidities such as prevention of HIV, or other areas of education such as undertaking risky sexual behaviors, were excluded from this review.

Following abstract coding, 50 papers were included for a full-text review. At the end of the full-text review, 42 papers were found to meet all our inclusion criteria and were included in the study. The specific steps of study selection and the number of papers included and excluded in each step can be seen in Figure 1 (flowchart for literature search and inclusion in Multimedia Appendix 2). After the study selection, information relevant to each of the main review questions was extracted and analyzed. We developed a standardized table (Multimedia Appendix 2) using these 42 papers selected to assess the different forms of CHIT used and their impact on the prevention of substance use. We also used this table to identify the different underlying behavioral frameworks most commonly at play in these interventions. Additionally, we also created a table to compile all the papers included in the reviews that are enlisted in this scoping review (Multimedia Appendix 3 [35-205]). 
Figure 1. Preferred Reporting Items for Systematic Reviews and Meta-Analyses flowchart for literature search process and inclusion.

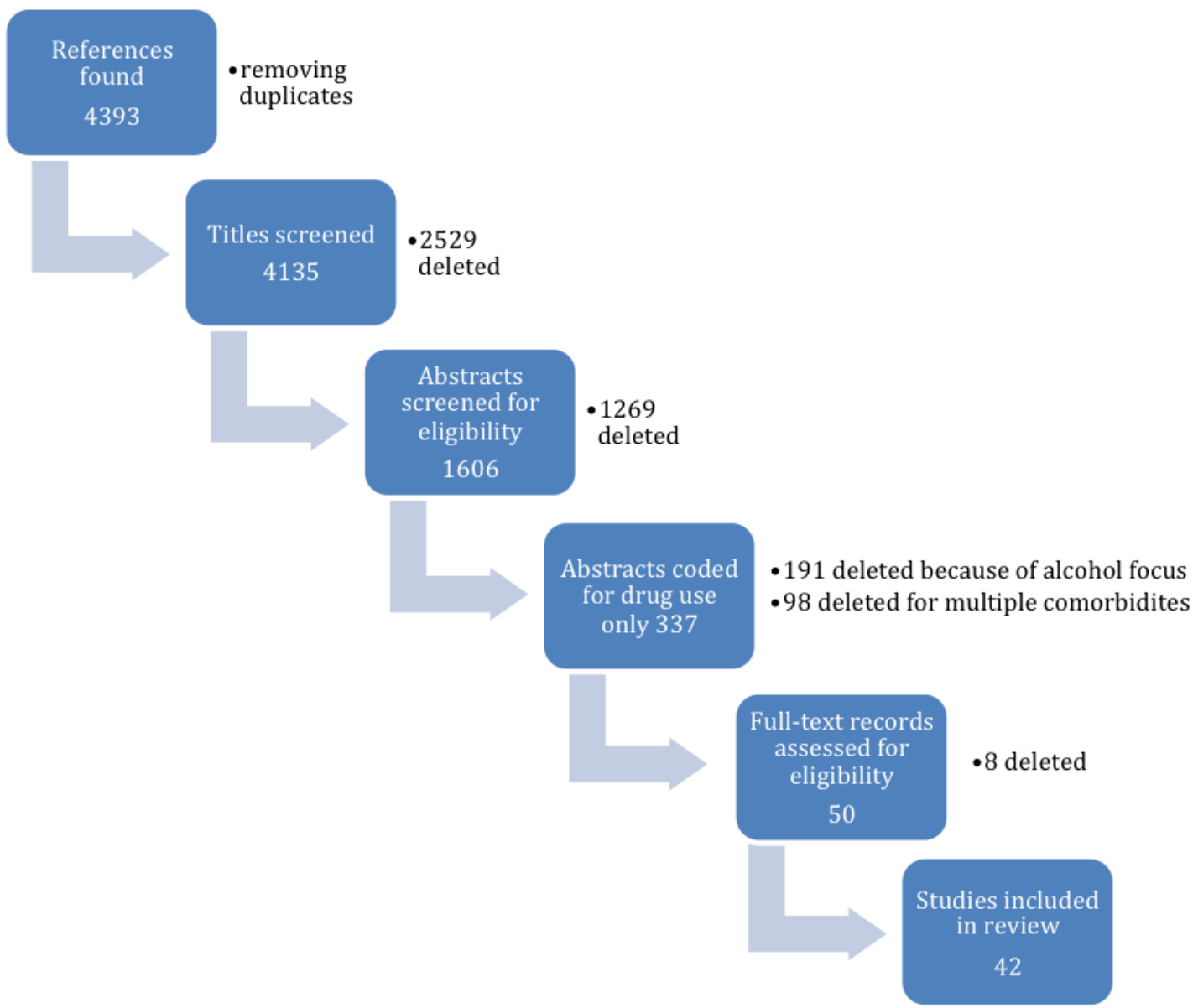

\section{Locations}

Most studies included in the review were conducted in the United States. Countries other than the United States were Canada [206-208], Australia [207-212], Brazil [213], the Netherlands [214], New Zealand [29], Norway [209,215,216], the United Kingdom [28,209,217], Germany [207], and Switzerland [218]. Moreover, 1 systematic review included 7 studies from the United States, and 1 from Norway [216]. Another study reviewed trials that took place in Australia, the Netherlands, the United Kingdom, and the United States [209]. In addition, 1 RCT took place in the United States and Canada [206]. A total of 6 studies included in the review were conducted in Australia. Within the United States, 1 randomized study recruited participants in West Virginia and Ohio [219]. Another RCT in the United States chose participants from 19 states and included Asian populations [220]. Furthermore, 1 study using Monitoring the Future survey data included nationally representative sample of students from 48 states [221]. Studies from other states in the United States recruited participants from California [30,222], New York [223], New Jersey [223], Connecticut [223], Texas [224], Kansas [222], Michigan [225], Missouri [222], and South Carolina [27]. Moreover, 1 study reported having participants mostly from rural communities in South Carolina [27]. Another study chose participants from schools in a semirural community in Michigan [225].

\section{Participants}

We did not exclude any studies in the review based on the demographic characteristics of participants. Therefore, study participants varied in ages, racial and ethnic backgrounds, and socioeconomic status. A total of 13 studies assessed school- or college-based intervention programs, and thus, participants were students, students with parents, or teachers [26,30,210,213,217,221,222,224-229]. Moreover, 1 quasi-experimental study included participants enrolled in vocational schools [218]. Similarly, 30 studies included only young people, adolescents, or school-aged children from 11 to 24 years of age. However, some systematic reviews assessed studies across all ages, both children and adults [207,230-233]. Some studies included only racial and ethnic minorities such as Asians [220], Hispanics [223], and African Americans [223]. Although some studies did not specify racial background of participants, 2 studies reported having study subjects from various races, including white, African American, Hispanic, and Asian [30,224]. Moreover, 1 study in the United Kingdom having subjects from 7 schools included 1 school with predominantly black students and the rest with mostly white students [217]. Another UK school-based study reported their participants were chosen to have a balance between both sexes, residence in rural and urban areas, and varying intellectual abilities [28]. A total of 4 studies specifically evaluated interventions on adolescent girls [220,223,234,235]. Of the 4 studies, 3 studies used a mother-daughter prevention approach $[220,223,227]$, assessing the impact of programs both on 
adolescent girls and their mothers. Moreover, 1 study selected participants only from economically disadvantaged African American adolescents [236].

\section{Sample Size}

A range of study sample size was included in the review. Overall, 1 systematic review had a total of 52,746 individuals as participants from 8 studies [215]. Other reviews included study sample sizes as small as 38 [207] to as large as 8352 [209]. Mother and daughter programs ranged from sample sizes of 206 to 916 girls and their mothers $[220,223,234]$. The nationally representative survey data included 337,918 cases [221]. Quasi-experimental studies also included both small $(\mathrm{n}=26)$ and large ( $\mathrm{n}=2882)$ sample sizes $[30,236]$. The RCTs reported larger sample sizes in general, ranging from 179 to 2332 participants [229].

\section{Comparators}

Of the 42 studies included in this review, Table 1 shows the different CHIT platforms used by the studies included. Moreover, 4 studies (Schuman et al, 1971; Milne et al, 1975; Pickens, 1984; and Eiser et al, 1988) looked at the effects of films as a part of educational programs to promote discussion around the areas of substance use [28,29,217,225]. The Schuman et al's (1971) study was a cross-sectional study conducted to evaluate the results of a field test implemented to emphasize on aspects such as motivations governing drug behaviors as opposed to drug facts [225]. The Milne et al's (1975) study used a pre-post study design [28], whereas the Eiser et al's (1988) study used an RCT design to assess the effectiveness of films as a medium of drug education [217]. The Pickens' (1984) study was a literature review aimed at assessing the effectiveness of films in drug education compared with other forms of media [29].

A total of 10 studies looked at the use of different mass media interventions in general. Of these, 7 studies (Wallack, 1980; Wallack, 1981; Bandy et al, 1983; Flay et al, 1983; Flay et al, 1986; Brinn et al, 2010; and Carson et al, 2017) were literature reviews, which evaluated the use and effectiveness of mass media as a tool for substance abuse prevention [215,216,226,231,237-239]. The Barcus et al (1975) and the Kinder's (1975) studies examined the impact of mass media on attitudes associated with increased substance use [230,240]. Although majority of the studies evaluated the impact of mass media on multiple drug use, the Brinn et al (2010) and the Carson et al's (2017) studies looked specifically into its role in smoking prevention [215,216]. The Miller et al's (1981) study used a cross-sectional survey design to compare effectiveness of media platforms such as television, radio, and newspaper in dissemination of substance abuse education [27]. Moreover, 5 studies looked specifically into the role of television and radio as modes of interventions. In addition, 3 studies (Feingold et al, 1977; Sussman et al, 1987; and Brannon et al, 1989) used a quasi-experimental design [26,30,222]. The Sussman's study and the Brannon's study used a school-based television program format [30,222], whereas Feingold (1977) and Terry-McElrath et al (2011) used television advertisements as their mode of intervention [26,221]. The Johnson et al's (1989) study was the only one that reviewed the strategies and research efforts in the use of radio and television [232].

Post 2009, there was a notable surge in the number of computerand internet-based interventions and a subsequent decrease in the number of mass media-based interventions. There were in total 18 studies that used Web-based and internet-based programs for interventions, whereas 5 studies used the desktop-enabled software or CD-ROM-based programs for interventions. Moreover, 13 of these studies used an RCT design and aimed to evaluate the effectiveness of computer-based substance abuse prevention programs. The Hansen et al, Newton et al (2014 and 2016), Christoff Ade et al (2015), and Andrews et al (2011 and 2014) studies evaluated the comparative effectiveness of computer-delivered prevention or screening programs with those termed as usual or traditional models of delivery [210-213,228,229,241]. In addition, 4 studies performed by Schinke et al compared the effectiveness of a mother-daughter-based program with a control group involving no intervention [220,223,227,234]. Furthermore, 2 studies by Schwinn et al tested the effect of an internet-based gender-specific drug prevention program between girls with and without an intervention [206,235]. Another 2 studies used the quasi-experimental pre-post study design, the Klisch et al's (2013) study compared the effectiveness between 2 different Web-based interactive programs [224], and the Moncher et al (1989) assessed the efficacy of the computer-delivered prevention programs [236]. Of the remaining studies, 5 studies were systematic reviews aimed at expanding the base of research and synthesizing the effectiveness of computer- and Web-based prevention programs.

The review by Carson et al (2017) and the randomized trial by Schwinn et al (2017) specifically included the effectiveness of social media as a component of the prevention programs [216,235]. In addition, a quasi-experimental (pre-post assessment) study by Haug et al (2017) and 2 systematic reviews by Jiang et al (2017) and Kazemi et al (2017) evaluated and critiqued the effectiveness of mobile phone-based prevention programs [218,233,242]. 
Table 1. Technology used as intervention in the 42 studies reviewed

\begin{tabular}{ll}
\hline Technology & Studies, n (\%) \\
\hline Computer & $6(10)$ \\
CD ROM & $5(9)$ \\
Film & $4(6)$ \\
Internet & $18(31)$ \\
Mass media & $6(10)$ \\
Mobile & $3(5)$ \\
Radio & $6(10)$ \\
Television & $11(19)$ \\
\hline
\end{tabular}

\section{Length of Observation}

Of the 42 studies reviewed here, 17 studies were in the form of systematic reviews spanning over the past 60 years. Of the remaining 27 studies, 8 studies had a short-term follow-up period of 1 month or less (Schuman et al; Milne et al, 1975; Feingold et al, 1977; Eiser et al, 1988; Moncher et al, 1989; Andrews et al, 2011; Deitz et al, 2011; and Klisch et al, 2013) [26,28,217,219,224,225,236,241]. Most of these studies used a cross-sectional pre-post assessment format. The long-term follow-up periods for most of the remaining studies ranged between 6 months (Schwinn et al, 2010; Champion et al, 2016; and Haug et al, 2017) to 1 year (Sussman et al, 1987; Schinke et al, 2009; Fang et al, 2010; Newton et al, 2014; Newton et al, 2016; and Schwinn et al, 2017) [30,206,210,212,218,220, 234,235]. In addition, 2 studies, Schinke et al's (2009) that evaluated computer-delivered program in preventing abuse among adolescent girls and Andrews et al's (2014) that assessed the long-term efficacy of a tobacco prevention program, had a follow-up period of 2 years [227,229]. The study by Christoff Ade et al in 2015 compared the efficacy of 3 different interventions, including a computer-delivered one, and followed its participants for 3 months [213]. The longest study period in this review was 10 years (Terry-McElrath et al, 2011); it evaluated the impact of antidrug advertisement exposure and campaign-specific exposure on the attitudes, beliefs, and behaviors among youths from 1995 to 2006 [221].

\section{Outcomes and Results}

Of the 4 studies that looked at films as the mode of intervention delivery, the Schuman et al's (1971) study found no significant difference in the identification of drug clues by geographical or socioeconomic differences [225]. It also found a large gap in perceptions about drugs among faculty and students [225]. The Milne et al's (1975) study found no significant difference in knowledge and attitudes toward drug use. Instead, results showed that students who believed drug use had social advantages also held onto the concept that the dangers of drug abuse were over exaggerated, a finding that thereby emphasizes the need for drug education [28]. The review study conducted by Pickens et al (1984) did not find film interventions superior to nonfilm approaches and found that the short-term impact of film interventions did not last in long-term follow-up studies [29]. However, the Eiser et al's (1988) study showed that an entertaining drug prevention film might be more effective in leading students to reject dangerous substances. In contrast, the students who viewed the educational film regarded both illegal and legal drugs to be similarly dangerous and addictive [217].

Studies that used mass media, radio, and television as modes of intervention found that neither of these platforms as stand-alone were adequate to bring about a change in the overall attitudes and behaviors of people who engage in substance use. The Barcus et al (1975), Wallack et al (1980), Wallack et al (1981), and Flay et al's (1983) studies found that mass media alone is not sufficient to affect behavioral changes and that it needs to be supplemented by school- or community-based prevention programs [215,216,230,231,237-240]. In addition, the literature reviews conducted on the use of mass media by Kinder (1975), Bandy et al (1983), Brinn et al (2010), Carson et al (2017), and a study by Sussman et al (1987) found either inconclusive or conflicting end results pertaining to the use of mass media in disseminating drug-related information and bringing about attitude changes [30,215,216,230,231]. Some studies (eg, Feingold et al, 1977) also found a boomerang effect of the use of television and radio, and antidrug messages were found to potentially lead to drug use [26]. Another exploratory study by Miller et al (1981) evaluated the comparative effectiveness among different mass media platforms such as television, radio, and newspaper and found that it depended on the demographics of the target audience: the results varied by race, sex, and geographical area [27]. Only the Brannon et al's study (1989) specifically looked at the effectiveness of television as a delivery format found it to have higher classroom participation rates, greater satisfaction, and higher perceived effectiveness for a combined television and classroom program, thus concluding it to be a viable option for wider implementation [222].

Post 2009, there was a notable increase in the number of studies that used computer- and Web-based interventions for substance use prevention. A total of 4 studies conducted by Schinke et al between 2009 and 2011 used mother-daughter dyads from different races to study the effectiveness of computer-delivered interventions based on the family interaction theory [220,223,227,234]. All studies found significant reductions in risk factors, drug use, and an increase in the protective factors. Some studies also showed improvements in the quality of mother-daughter relationships. Moreover, 2 studies conducted by Schwinn et al in 2010 and 2017 used gender-specific interventions for girls using internet and social media platforms. 
These studies found reduced 30-day alcohol, marijuana, poly-drug, and total substance use at 6-month and 1-year follow-up [206,235]. The 2017's study also found material changes in the cognition and skills that are empirically linked to drug use risks [235]. In addition, 2 studies by Andrew et al in 2011 and 2014 analyzed the short- and long-term efficacy of Click City tobacco intervention and found that the intervention had the potential to significantly postpone or prevent the initiation of cigarette use and regular smoking among students. In addition, although in the short term, the intervention showed moderate effectiveness at changing intentions to use smokeless tobacco in the future, the effect did not persist in the long term [229,241]. Another study (Deitz et al, 2011) that evaluated the effect of the Smart Rx Web program found that it significantly increased participants' knowledge of proper prescription drug use and improved their self-efficacy in ability to manage and adhere to appropriate treatments [219].

Multiple studies identified in this review had used school-based programs for the delivery of Web-based interventions; 3 of these conducted by Newton et al between 2013 and 2016 in Australia used the climate schools format for the prevention of use of drugs such as cannabis, alcohol, ecstasy, and new psychoactive substances (NPS) [210-212]. These studies not only found evidence that internet-based preventive interventions significantly decreased substance use but also demonstrated that they could concurrently reduce associated risk factors in adolescents. However, the intervention neither significantly changed binge drinking and cannabis nor ecstasy and NPS use in the short term; the effects of these interventions were only apparent after 12 months, thereby showing a time-delayed effect, which could be attributed to the time required by the students to experience and implement the strategies learned [212]. The Hansen et al's study in 2009 that evaluated the efficacy of Web-based components to facilitate program implementation concluded that school-based prevention programs could benefit from adding Web-based components to improve ease of implementation and enthusiasm of teachers [228]. The Klisch et al's (2013) study, which used interactive game sessions in 11 th and 12th graders, found the intervention to be effective in promoting healthier attitudes toward nonmedical use of prescription drugs [224]. Similarly, the Haug study in 2017, which used a mobile phone-based intervention found that it improved study participation, retention, and improved effectiveness with a statistically significant increase in the life skills and self-management skills and reduction in the number at risk for alcohol use [218]. However, a study conducted by Christoff Ade et al in 2015 could not find conclusive evidence of effectiveness of computer-based intervention among college students for reducing substance use [213].

A total of 4 systematic reviews conducted by Champion et al (2013 and 2016), Wood et al (2014), and Hopson et al (2015) on the use of computer- and internet-based programs found them to be potentially efficacious methods of delivering drug prevention programs. The Champion et al's reviews found greatest effects in relation to drug- and alcohol-related knowledge with persisting effectiveness at 6- and 12-month follow-ups [209,214]. The Wood et al's review, on the other hand, emphasized the need for further research to better understand the value of human contact in health interventions and to determine the optimal levels of professional input [207], whereas the Hopson et al's (2015) review identified computerand internet-based programs as cost-effective options for reaching more individuals, but on the whole reported mixed findings in terms of the effectiveness over traditional methods [208]. In addition, 2 reviews conducted by Jiang et al (2017) and Kazemi et al (2017) reviewed the use of telephone and mobile technology in substance use prevention and found that although it was a promising means to address substance use, the studies included in the reviews for the most part showed either inconclusive or mixed results in terms of the efficiency and efficacy $[233,242]$.

\section{Discussion}

\section{Principal Findings}

This review included studies spanning across the globe, with the target population for these studies ranging across varying age groups, race or ethnicity, and gender and having differing study designs and sample sizes. The period for the literature search ranged from 1809 to January 2018, but the search only captured studies going as back as the early 1950s. This could be attributed to the fact that the review only included studies that had digitalized records enlisted on the databases searched. However, it can be said with fair amount of certainty that this review manages to capture majority of the trends in the use of CHIT. The boom in the use of media and CHIT platforms was seen to have occurred post the Second World War, thereby reaffirming the validity of the literature search timeline [243].

This review explored multiple CHIT platforms such as television, radio, films, mass media, computer, CD-ROM, internet, social media, and mobile. It was observed that from 1971 to 1989 , film, televison, radio, and mass media were the most commonly used modes of intervention [26-30,217,222,225,226,230-232,236-240], whereas post 2009, there was a greater emphasis on the use of computer- and internet-based interventions [206-215,219-221,223,224,227-229, 234,241]. Furthermore, recent years show a growing emphasis toward exploring the role of social media- and mobile phone-based interventions to expand the reach of these prevention programs [216,218,233,235,242].

CHIT-based interventions have been shown to overcome challenges imposed by in-person-delivered intervention strategies such as the need for trained personnel to prepare and deliver intervention programs [218]. In addition, studies that examined the impact of electronic health and mobile health (mHealth) interventions found them to be efficacious and cost-effective, with computer-based interventions being more cost-effective than other preventive measures that are labor intensive and costly such as Life Skills Training Program [244]. In our study, the use of media and technology to prevent substance abuse was also found to have several advantages as a prevention strategy. Technology-based interventions can facilitate rapid dissemination of information and improving knowledge about substance use [220,236,238,240]. They can also reduce intervention variability that may occur with a person-based intervention method [226], improving integrity 
of intervention measures. In addition, intervention recipients, especially nonabusers who are ideal candidates for primary prevention, are more likely to depend on the media to gain information and knowledge about substance abuse [228].

Studies based on the family interaction theory and aimed at improving relationship quality among mother-daughter duos and studies that were gender-based were found to be effective in reducing the substance use in both the long and short term $[220,223,227,234,235]$. Multiple studies included in the review used school-based programs for delivery of Web-based interventions; of these, the climate school studies conducted in Australia not only found evidence that internet-based preventive interventions significantly decreased substance use but also demonstrated that they can concurrently reduce associated risk factors in adolescents [209-212,214]. However, the intervention did not show significant impact in the short-term use of substances; the effects of these interventions were only apparent after 12 months, thereby showing a time-delayed effect, attributed to the time required by the students to experience and implement strategies learnt [209,211,212]. Other studies that explored the effectiveness of school-based programs using Web-based or mobile phone-based interventions also found similar results. The studies that focused on the use of social media and mHealth platforms suggested the growth of research and literature in this domain [216,218,233,235,242].

However, in this study, we also found that technology-based interventions are not a panacea in the prevention of substance abuse. Despite the great number of resources poured into development and implementation of media- and technology-based interventions, earlier and recent studies demonstrated moderate effectiveness of these strategies in changing attitude, and ultimately, behavior of recipients of interventions [210,228,235-239]. Although in cases where people may gain greater and more accurate knowledge in substance abuse and negative consequences ensuing from the use, studies failed to show the changes in terms of decreasing or terminating the use or abuse of substance because of these interventions [228,236,237]. For example, studies that explored the role of film, television, radio, and mass media did not find any conclusive evidence to support the stand-alone effectiveness of these platforms. Most of the studies concluded that these platforms should be used in conjunction with other prevention initiatives [26,28,30,222,225,226,237-240].

This review also shows a gradual shift in the types and use of CHIT platforms over the past few decades. It has slowly moved from mass media-based interventions toward Web-based interventions, and following the current trends is heading toward a greater emphasis on telehealth and mHealth-based interventions. We live in an age in which most people frequently use technology and social media and are acutely aware of the current opioid misuse and substance abuse predicament facing by the United States in general and the world at large [22,245]. In this social context, technology could be useful to reach the general population as well as specific at-risk population and potentially be used to develop more tailored and effective prevention. In particular, because adolescents are frequent and avid users of various types of latest technology, computers and smartphones among other technologies could potentially be powerful tools in the primary prevention of substance abuse [218]. Thus, we are quite confident that future research should be focused more on leveraging the use of current CHIT platforms such as mobiles and social media to enhance the outreach of substance abuse prevention programs.

\section{Limitations}

This study has multiple strengths and is unique in its approach to map the changing trends in the use of CHIT for substance abuse prevention. It covers a long period and spans across the globe. By design, it did not capture technological interventions for alcohol prevention, as a stand-alone review on the prevention of alcohol abuse would be more appropriate. It is also seen that there was a gap in the literature between 1990 and 2008, no studies during this period were included, and this could be attributed to the stringent eligibility criteria for this review. For study limitations, the review solely focuses on primary prevention and hence, fails to capture the use of CHIT in secondary prevention and its role in treatment of substance use.

The focus of the study on primary prevention of substance abuse necessitated the exclusion of a large number of studies; however, there is an opportunity to follow on with subsequent studies to fill this gap. For example, by design, the study did not capture the effects and correlation between substance use and comorbidities such as HIV and risky health behaviors and the use of CHIT to either treat or prevent either of the repercussions of these correlations. It did not include studies conducted in special populations such as cancer patients and patients with HIV, AIDS, or other STDs. This review also did not include a large number of studies that explored the use of mobile and social media platforms as vehicles of intervention delivery, as opposed to providing prevention programs. This again could be attributed to the stringent eligibility criteria.

\section{Conclusions}

This review shows a gradual shift in the types and use of CHIT platforms over the past few decades for substance abuse prevention. It captures the progression from mass media-based interventions toward Web-based intervention and the current trends that head toward a greater emphasis on telehealth- and mHealth-based interventions while emphasizing the need for further development and study of these interventions. It also highlights the gradual shift in consumer and participant behavior, wherein preferences have slowly moved from face-to-face interactions toward more Web- and technology-based platforms, given the anonymity and the vast outreach that these platforms offer. Studies included in this review found these technologies to be effective and cost-effective in real-world settings and contexts. Taking into account the familiarity and ease of use of these CHIT platforms among adults and youth alike, we now have an opportunity to further leverage these platforms for substance use prevention. 


\section{Acknowledgments}

The views expressed in this report are those of the authors alone. The authors would like to thank the librarian at the University of Maryland, School of Pharmacy, for her assistance with the literature search.

\section{Authors' Contributions}

FTS, AMP, and JF conceived the study and contributed to the design of the scoping review. AP and LP contributed to the execution and analysis of the scoping review. FTS and JF contributed significant intellectual content presented in this paper as expert members on the team. All authors were involved in writing the paper. All authors read and approved the final manuscript.

\section{Conflicts of Interest}

None declared.

\section{Multimedia Appendix 1}

Search terms used.

[PDF File (Adobe PDF File), 71KB-Multimedia Appendix 1]

\section{Multimedia Appendix 2}

Summary of articles by study design, CHIT used, and outcomes.

[PDF File (Adobe PDF File), 252KB-Multimedia Appendix 2]

\section{Multimedia Appendix 3}

Details on articles included in the reviews cited in the manuscript.

[PDF File (Adobe PDF File), 264KB-Multimedia Appendix 3]

\section{References}

1. Columbia CASA. Center On Addiction. 2012. Addiction medicine: closing the gap between science and practice URL: https://www.centeronaddiction.org/addiction-research/reports/ addiction-medicine-closing-gap-between-science-and-practice[WebCite Cache ID 70qGo7G8C]

2. National Institute on Drug Abuse. 2017. Trends and Statistics URL: https://www.drugabuse.gov/related-topics/trends-statistics [accessed 2018-07-11] [WebCite Cache ID 70qH99whJ]

3. American Addiction Centers. 2018. Statistics on Drug Addiction URL: https://americanaddictioncenters.org/rehab-guide/ addiction-statistics/ [accessed 2018-07-12] [WebCite Cache ID 70qVoKjh9]

4. Rehm J, Mathers C, Popova S, Thavorncharoensap M, Teerawattananon Y, Patra J. Global burden of disease and injury and economic cost attributable to alcohol use and alcohol-use disorders. Lancet 2009 Jun 27;373(9682):2223-2233. [doi: 10.1016/S0140-6736(09)60746-7] [Medline: 19560604]

5. Centers for Disease Control and Prevention. Centers for Disease Control and Prevention. 2014. Best Practices for Comprehensive Tobacco Control Programs Atlanta URL: https://www.cdc.gov/tobacco/stateandcommunity/best_practices/ pdfs/2014/comprehensive.pdf[WebCite Cache ID 70xUULp4q]

6. National Drug Intelligence Center. United States Department of Jusitce. 2011. The Economic Impact of Illicit Drug Use on American Society URL: http://www.simeoneassociates.com/assets/pdfs/SAI_Assessment1.pdf [accessed 2018-07-17] [WebCite Cache ID 70yybZm6W]

7. Gianluca QG. European Parliament. 2017. Technological innovation strategies in substance use disorders URL: http://www. europarl.europa.eu/RegData/etudes/STUD/2017/581942/EPRS_STU(2017)581942_EN.pdf[WebCite Cache ID 70rJTntzC]

8. Abuse N. National Institute of Drug Abuse. 2017. Overdose Death Rates URL: https://www.drugabuse.gov/related-topics/ trends-statistics/overdose-death-rates [accessed 2018-07-12] [WebCite Cache ID 70rZwZgUW]

9. Sloboda Z, Bukoski WJ. The Emerging Science of Drug Abuse Prevention. In: Handbook of drug abuse prevention. Boston: Springer; 2006.

10. National Institute on Alcohol Abuse and Alcoholism. National Institute of Health. 2005. Preventing Alcohol Abuse and Dependence URL: https://pubs.niaaa.nih.gov/publications/social/module3prevention/module3.html [accessed 2018-10-04] [WebCite Cache ID 72vll5lxG]

11. Medina-Mora M. Prevention of substance abuse: a brief overview. World Psychiatry 2005 Feb;4(1):25-30 [FREE Full text] [Medline: 16633497]

12. Substance Abuse and Mental Health Services Administration. 2018. Prevention of Substance Abuse and Mental Illness URL: https://www.samhsa.gov/prevention [accessed 2018-10-05] [WebCite Cache ID 72vmdenrG] 
13. Gibbons M, Wilson R, Samal L, Lehmann C, Dickersin K, Lehmann H, et al. Consumer health informatics: results of a systematic evidence review and evidence based recommendations. Transl Behav Med 2011 Mar;1(1):72-82 [FREE Full text] [doi: 10.1007/s13142-011-0016-4] [Medline: 24073033]

14. Or CK, Karsh B, Severtson DJ, Burke LJ, Brown RL, Brennan PF. Factors affecting home care patients' acceptance of a web-based interactive self-management technology. J Am Med Inform Assoc 2011 Feb;18(1):51-59 [RREE Full text] [doi: 10.1136/jamia.2010.007336] [Medline: 21131605]

15. Gustafson DH, Hawkins RP, Boberg EW, McTavish F, Owens B, Wise M, et al. CHESS: 10 years of research and development in consumer health informatics for broad populations, including the underserved. Int J Med Inform $2002 \mathrm{Nov}$ 12;65(3):169-177. [Medline: $\underline{12414016]}$

16. Lewis D, Eysenbach G, Kukafka R. Consumer Health Informatics: Informing Consumers and Improving Health Care. New York: Springer-Verlag; 2005.

17. Tao D, Wang T, Wang T, Liu S, Qu X. Effects of consumer-oriented health information technologies in diabetes management over time: a systematic review and meta-analysis of randomized controlled trials. J Am Med Inform Assoc 2017 Sep 01;24(5):1014-1023. [doi: 10.1093/jamia/ocx014] [Medline: 28340030]

18. Or C, Karsh B. A systematic review of patient acceptance of consumer health information technology. J Am Med Inform Assoc 2009;16(4):550-560 [FREE Full text] [doi: 10.1197/jamia.M2888] [Medline: 19390112]

19. Finkelstein J, Knight A, Marinopoulos S, Gibbons MC, Berger Z, Aboumatar H, et al. Enabling patient-centered care through health information technology. Evid Rep Technol Assess (Full Rep) 2012 Jun(206):1-1531. [Medline: 24422882]

20. PEW Research Center. 2018. Demographics of Internet and Home Broadband Usage in the United States URL: http://www. pewinternet.org/fact-sheet/internet-broadband/[WebCite Cache ID 70raT3uGu]

21. PEW Research Center. Three Technology Revolutions URL: http://www.pewinternet.org/three-technology-revolutions/ [accessed 2018-07-12] [WebCite Cache ID 70rawUWun]

22. World Health Organisation. E-health technologies and substance abuse URL: $\underline{\text { http://www.who.int/substance abuse/activities/ }}$ ehealth/en/[WebCite Cache ID 70rbPY4gk]

23. Marsch LA, Borodovsky JT. Technology-based interventions for preventing and treating substance use among youth. Child Adolesc Psychiatr Clin N Am 2016 Dec;25(4):755-768. [doi: 10.1016/j.chc.2016.06.005] [Medline: $\underline{27613350]}$

24. Moore BA, Fazzino T, Garnet B, Cutter CJ, Barry DT. Computer-based interventions for drug use disorders: a systematic review. J Subst Abuse Treat 2011 Apr;40(3):215-223 [FREE Full text] [doi: 10.1016/j.jsat.2010.11.002] [Medline: 21185683]

25. Young SD, Swendeman D, Holloway IW, Reback CJ, Kao U. Use of technology to address substance use in the context of HIV: a systematic review. Curr HIV/AIDS Rep 2015 Dec;12(4):462-471 [FREE Full text] [doi: 10.1007/s11904-015-0295-3] [Medline: 26475670]

26. Feingold PC, Knapp ML. Anti-drug abuse commercials. J Commun 1977;27(1):20-28. [Medline: $\underline{833346]}$

27. Miller MC, Cantor AB, Larisey L, Murphy E. Comparison of media for substance abuse education in rural communities. Int J Addict 1981 May;16(4):585-592. [Medline: 7287242]

28. Milne HB, Butt TW. The critical assessment of the T.V. film “The Drug Takers”. Br J Addict Alcohol Other Drugs 1975 Jun;70(2):216-220. [Medline: 1058026]

29. Pickens KA. The use of films in drug education--a review. Health Educ J 1984;43(4):19-20. [Medline: 10317570$]$

30. Sussman S, Flay B, Sobel J, Rauch J, Hansen W, Johnson C. Viewing and evaluation of a televised drug education program by students previously or concurrently exposed to school-based substance abuse prevention programming. Health Educ Res 1987;2(4):373-383. [doi: 10.1093/her/2.4.373]

31. Arksey H, O'Malley L. Scoping studies: towards a methodological framework. Int J Soc Res Methodol 2005 Feb;8(1):19-32. [doi: $\underline{10.1080 / 1364557032000119616]}$

32. Levac D, Colquhoun H, O'Brien KK. Scoping studies: advancing the methodology. Implement Sci 2010;5:69 [FREE Full text] [doi: 10.1186/1748-5908-5-69] [Medline: 20854677]

33. Faulkner GE, Grootendorst P, Nguyen VH, Andreyeva T, Arbour-Nicitopoulos K, Auld MC, et al. Economic instruments for obesity prevention: results of a scoping review and modified Delphi survey. Int J Behav Nutr Phys Act 2011 Oct 06;8:109 [FREE Full text] [doi: 10.1186/1479-5868-8-109] [Medline: 21978599]

34. Bottorff JL, Haines-Saah R, Kelly MT, Oliffe JL, Torchalla I, Poole N, et al. Gender, smoking and tobacco reduction and cessation: a scoping review. Int J Equity Health 2014 Dec 12;13:114 [FREE Full text] [doi: 10.1186/s12939-014-0114-2] [Medline: 25495141]

35. Kanter D. The drug scene: current research. Public Opin Q 1971 Sep 01;35(3):459-463. [doi: 10.1093/poq/35.3.459]

36. O'Keefe M. The Anti-Smoking Commercials: A Study of Television's Impact on Behavio. Public Opin Q 1971;35(2):242-248 [FREE Full text]

37. Fejer D, Smart R, Whitehead P, Laforest L. Sources of information about drugs among high school students. Public Opin Q 1971;35(2):235-241. [doi: 10.1086/267895]

38. Hanneman G. Sources of Drug Abuse Information on the College Campus. Connecticut: University of Connecticut; 1972.

39. Linsky AS. The changing public views of alcoholism. Q J Stud Alcohol 1970 Sep;31(3):692-704. [Medline: 5466398]

40. Lipp M, Benson S, Taintor Z. Marijuana use by medical students. Am J Psychiatry 1971 Aug;128(2):207-212. [doi: 10.1176/ajp.128.2.207] [Medline: 5112947] 
41. Pollock SH. Attitudes of medical students toward marijuana. J Psychoactive Drugs 2012 Jan 17;5(1):56-61. [doi: 10.1080/02791072.1972.10471470]

42. Grant J. Drug education based on a knowledge, attitude, and experience study. J Sch Health 1971 Sep;41(7):383-386. [Medline: 5208626]

43. Zajonc RB. Attitudinal effects of mere exposure. J Pers Soc Psychol 1968;9(2, Pt.2):1-27. [doi: 10.1037/h0025848]

44. Amendolara F. Modifying attitudes towards drugs in seventh grade students. J Drug Educ 1995 Jan;3(1):71-78. [doi: 10.2190/WL56-DEV7-441M-LDDW]

45. Braxton ER, Yonker RJ. Does being urban, poor, black, or female affect youth's knowledge and-or attitudes relating to drugs? J Sch Health 1973 Mar;43(3):185-188. [Medline: 4486608$]$

46. Einstein S, Lavehar M, Garitano WW. Drug abuse education and the multiplier effect: an experience in training 109 teachers. J Sch Health 1972 Dec;42(10):609-613. [Medline: 4485223]

47. Einstein S, Lavenhar MA, Wolfson EA, Louria DB, Quinones MA, McAteer G. The training of teachers for drug abuse education programs: preliminary considerations. J Drug Educ 1995 Jan;1(4):323-345. [doi: 10.2190/12A7-WQR7-1B27-J2DF]

48. Richardson DW, Nader PR, Roghmann KJ, Friedman S. Attitudes of fifth grade students to illicit psychoactive drugs. J Sch Health 1972 Sep;42(7):389-391. [Medline: 4483996]

49. Irwin R, Creswell W, Stauffer D. The effect of the teacher and three different Classroom approaches on seventh grade students? Knowledge, attitudes and beliefs about smoking*. J Sch Health 1970;40(7):355-359. [doi:

10.1111/j.1746-1561.1970.tb05622.x]

50. Levitt L, Baganz P, Blachly P. A study of employee attitudes toward patients in a hospital for the treatment of drug addiction. Psychiatr Q 1963 Apr;37:210-219. [Medline: 13930213]

51. Shaw CT. Knowledge and attitude responses of college students toward controversial social health issues. J Sch Health 1972 Jan;42(1):53-56. [Medline: 4480910]

52. Barcus F. Drug advertising on television. In: Drug Use in America: Problem in Perspective. Washington, DC: Irvington Pub; 1973.

53. Hanneman G, Eisenstock B, Weinbeck W. The medicine man message: an evaluation of a California state office of narcotics and drug abuse prevention campaign to inform the public of the dangers of prescription and over-the -counter drug misuse. California: University of Southern California, Pacific Institute for Research and Evaluation; 1977.

54. Warner KE. The effects of the anti-smoking campaign on cigarette consumption. Am J Public Health 1977 Jul;67(7):645-650. [Medline: $\underline{879393]}$

55. Wotring C, Heald G, Carpenter C. Evaluation of the Florida drug abuse campaign (1976-1977). Florida state university: College of communication; 1977.

56. Wallack L. An assessment of drinking patterns, problems., knowledge and attidtudes in three Northern California communities. Social research group 1978;Contract No:C21.

57. Brecher EM. Licit and Illicit Drugs: The Consumers Union Report on Narcotics, Stimulants, Depressants, Inhalants, Hallucinogens, and Marijuana - Including Caffeine, Nicotine, and Alcohol. United States: Little, Brown and Company; 1973.

58. Lazarsfeld P, Merton RK. Mass communication, popular taste,organized social aciton. In: Schramm W, Roberts D, editors. The process and effects of mass communication. Revised edition. United States: University of Illinois Press; 1971.

59. Fishbein F. Consumer beliefs and behavior with respect to cigarette smoking : a critical analysis of the public literature. A report prepared for the staff of the Federal Trade Commission. Champaign, Ill: University of Illinois at Champaign-Urbana; 1977.

60. Department of national health and welfare. Long range health planning b, non-medical use of d. Smoking and health in Canada 1977.

61. Hanneman G, McEwen W. Televised drug abuse appeals: a content analysis. Journal Mass Commun Q 2016 Aug 29;50(2):329-333. [doi: 10.1177/107769907305000216]

62. Schlegel R. The role of persuasive communications in drug dissuasion. J Drug Educ 1995 Jan;7(3):279-290. [doi: 10.2190/XWTJ-X7CT-0PGD-Y70E]

63. Dembo R, Schmeidler J, Lipton DS, Babst DV, Diamond SC, Spielman CR, et al. A survey of students' awareness of and attitudes toward drug abuse prevention programs in New York State, winter 1974/75. Int J Addict 1979 Apr;14(3):311-328. [Medline: 468427]

64. Kline JA. Evaluation of a Multimedia Drug Education Program. J Drug Educ 1995 Jan;2(3):229-239. [doi: 10.2190/NW0E-8FQU-N6RN-68QP]

65. Dembo R, Miran M, Babst DV, Schmeidler J. The believability of the media as sources of information on drugs. Int J Addict 1977 Oct;12(7):959-969. [Medline: 591149]

66. Smart R, Fejer D. Credibility of sources of drug information for high school students. J Drug Issues 1972 Apr;2(2):8-18. [doi: $10.1177 / 002204267200200204]$

67. Milavsky J, Pekowsky B, Stipp H. TV drug advertising and proprietary and illicit drug use among teenage boys*. Public Opin Q 1975;39(4):457-481. [doi: 10.1086/268244] 
68. Payne D. The Relationship between Television Advertising and Drug Abuse among Youth: Fancy and Fact. New York: Baywood Publishing Co; 1976:215-220.

69. Kohn P, Snook S. Balanced vs. one-sided communications about drugs. J Drug Educ 1995 Jan;6(4):273-281. [doi: 10.2190/M3LL-K013-VRUY-WLGP]

70. Wotring C, Heald G, Carpenter C, Schmeling D. Attacking the drug norm: effects of the 1976-77 Florida Drug Abuse TV Campaign. J Drug Educ 1995 Jan 25;9(3):255-261. [doi: 10.2190/1AFQ-GHM7-JL7U-U7VA]

71. Schmeling D, Wotring C. Agenda-setting effects of drug abuse public service ads. J Q 2016 Aug 29;53(4):743-746. [doi: 10.1177/107769907605300424]

72. Hanneman G. The medicine man message: a delayed effects evaluation of a California state office of narcotics and drug abuse prevention campaign to inform the public of the dangers of prescription and over-the -counter drug misuse. In: University of Southern California, Center for communications policy research. United States: University of Southern California; 1978:a.

73. Sandmaier M. Sandmaier M. Myths and messages: using the media as a prevention tool, in the women next door: summary proceedings of a symposium on the subject of drugs and the modern women. US journal of drug and alcohol dependence 1980:a.

74. Capalaces R, Starr J. The negative message of anti-drug spots: does it get across? Public Telecommunications Review 1973;1:64-66.

75. Delaney R. Florida study looks at effects of media messages. National Institute of Alcohol Abuse and Alcoholism information and feature service 1981:5.

76. Dickman FB, Keil TJ. Public television and public health. The case of alcoholism. J Stud Alcohol 1977 Mar;38(3):584-592. [Medline: $\underline{859338]}$

77. Field T, Deitrick S, Hersey J, Probst J, Theologus G. Implementing public education campaigns:lessons from alcohol abuse prevention. Summary report to NIAAA. Washington, DC: Kappa systems; 1983.

78. Hanneman GJ, McEwen WJ, Coyne SA. Public service advertising on television. Journal of Broadcasting 1973 Sep;17(4):387-404. [doi: 10.1080/08838157309363703]

79. Morrison A, Kline F, Miller P. Aspects of adolescent information acquisition about drugs alcohol topics. In: Ostman R, editor. Communication Research and Drug Education. London: Sage publication; 1976.

80. Plant MA, Pirie F, Kreitman N. Evaluation of the Scottish Health Education Unit's 1976 campaign on alcoholism. Soc Psychiatry 1979;14(1):11-24. [doi: 10.1007/BF00583569]

81. Rappeport M, Labow P. The public evaluates the NIAAA public education campaign: a sudy for the U.S. department of health, education, welfare, public health service, alcohol, drug abuse, and mental health administration. Princeton, New Jersey: Opinion research corporation; 1975.

82. Trager R. Adolescent reactions to educational media messages regarding drug education. In: Ostman R, editor. Communication research and drug education. London: Sage Publications; 1976.

83. Wong M, Barbatsis G. Attitude and information change effected by drug education via broadcast television and group viewing. J Drug Education 1976;8(2):161.

84. Weimer J. The effects of film treatments on attitudes that correlated with drug-behavior. South Dakota: University of South Dakota; 1976.

85. English GE. The effectiveness of emotional appeal versus fact-giving drug educational films. J Sch Health 1972;42(9):540-541. [doi: 10.1111/j.1746- 1561.1972.tb00975.x]

86. Swift B, Dorn N, Thompson A. Evaluation of drug education : findings of a national research study of effects on secondary school students of five types of lessons given by teachers. London: Institute for the study of drug dependence; 1974.

87. Thornell J. The construction and evalution of drug education of a drug education programme for third grade students. Boston, MA: Boston College; 1976.

88. Sohn M. Change in factual knowledge and reported use of illicit drugs resulting from the viewing of a motion picture. United States: University of Maryland; 1976.

89. Taussig W. The effects of a family life program and a drug education program on the self esteem of fifth grade children. New York: New York University; 1978.

90. Rosengren K, Wenner L, Palmgreen P. Media Gratifications Research: Current Perspectives. London: SAGE Publications; 1985.

91. Flay B, Pentz M, Johnson C, Sussman S. Reaching children with mass media health promotion programs: the relative effectivenss of an advertising campaign, a community-based programa school-based program. In: Leather G, editor. Health evaluation and the media. Pergamon: Journal of School Health; 1986.

92. Flay B. Psychosocial approaches to smoking prevention: a review of findings. Health Psychol 1985;4(5):449-488. [Medline: 3908090]

93. Flay BR. Mass media and smoking cessation: a critical review. Am J Public Health 1987 Feb;77(2):153-160. [Medline: 3541650]

94. National Coalition of Hispanic Health and Human Services Organization. Early intervention with Hispanic youth. Washington, DC: Office for Substance Abuse Prevention, Alcohol, Drug Abuse and Mental Health Administration. (COSSMHO); 1988. 
95. Amaro H, Campa R, Coffman G, Heeren T. Initiation of substance abuse among Mexican American, Cuban American, and Puerto Rican adolescents and young adults:findings from the Hispanic HANES. Am J Public Health 1989.

96. Booth M, Castro F, Anglin M. What do we know about Hispanic substance abuse? a review of the literature. In: Glick R, Moore J, editors. Drugs in Hispanic communities. New Brunswick, NJ: Rutgers University Press; 1989.

97. Caetano R, Martinez R. Alcohol use in Madrid and among U.S. Hispanics. Berkeley, CA: The National Institute on Alcohol Abuse and Alcoholism; 1987.

98. Buller DB, Borland R, Woodall WG, Hall JR, Hines JM, Burris-Woodall P, et al. Randomized trials on consider this, a tailored, internet-delivered smoking prevention program for adolescents. Health Educ Behav 2008 Apr;35(2):260-281 [FREE Full text] [doi: 10.1177/1090198106288982] [Medline: 17114331]

99. Norman CD, Maley O, Li X, Skinner HA. Using the internet to assist smoking prevention and cessation in schools: a randomized, controlled trial. Health Psychol 2008 Nov;27(6):799-810. [doi: 10.1037/a0013105] [Medline: 19025276]

100. Prokhorov AV, Kelder SH, Shegog R, Murray N, Peters Jr R, Agurcia-Parker C, et al. Impact of A Smoking Prevention Interactive Experience (ASPIRE), an interactive, multimedia smoking prevention and cessation curriculum for culturally diverse high-school students. Nicotine Tob Res 2008 Sep;10(9):1477-1485. [doi: 10.1080/14622200802323183] [Medline: 19023839]

101. Vogl L, Teesson M, Andrews G, Bird K, Steadman B, Dillon P. A computerized harm minimization prevention program for alcohol misuse and related harms: randomized controlled trial. Addiction 2009 Apr;104(4):564-575. [doi: 10.1111/j.1360-0443.2009.02510.x] [Medline: 19335655$]$

102. Newton NC, Vogl LE, Teesson M, Andrews G. CLIMATE Schools: alcohol module: cross-validation of a school-based prevention programme for alcohol misuse. Aust N Z J Psychiatry 2009 Mar;43(3):201-207. [doi: 10.1080/00048670802653364] [Medline: 19221908]

103. Newton NC, Andrews G, Teesson M, Vogl LE. Delivering prevention for alcohol and cannabis using the Internet: a cluster randomised controlled trial. Prev Med 2009 Jun;48(6):579-584. [doi: 10.1016/j.ypmed.2009.04.009] [Medline: 19389420]

104. Newton NC, Teesson M, Vogl LE, Andrews G. Internet-based prevention for alcohol and cannabis use: final results of the Climate Schools course. Addiction 2010 Apr;105(4):749-759. [doi: 10.1111/j.1360-0443.2009.02853.x] [Medline: 20148791]

105. Koning IM, Vollebergh WA, Smit F, Verdurmen JEE, Van Den Eijnden RJ, Ter Bogt TF, et al. Preventing heavy alcohol use in adolescents (PAS): cluster randomized trial of a parent and student intervention offered separately and simultaneously. Addiction 2009 Oct;104(10):1669-1678. [doi: 10.1111/j.1360-0443.2009.02677.x] [Medline: 21265908]

106. Aveyard P, Sherratt E, Almond J, Lawrence T, Lancashire R, Griffin C, et al. The change-in-stage and updated smoking status results from a cluster-randomized trial of smoking prevention and cessation using the transtheoretical model among British adolescents. Prev Med 2001 Oct;33(4):313-324. [doi: 10.1006/pmed.2001.0889] [Medline: 11570836]

107. Marsch LA, Bickel WK, Grabinski MJ. Application of interactive, computer technology to adolescent substance abuse prevention and treatment. Adolesc Med State Art Rev 2007 Aug;18(2):342-56, xii. [Medline: 18605650]

108. Duncan TE, Duncan SC, Beauchamp N, Wells J, Ary DV. Development and evaluation of an interactive CD-ROM refusal skills program to prevent youth substance use: "refuse to use". J Behav Med 2000 Feb;23(1):59-72. [Medline: 10749011]

109. Lord S, D'Amante D. Efficacy of online alcohol and other drug prevention for early adolescents. J Adolesc Health 2007 Feb;40(2):S4. [doi: 10.1016/j.jadohealth.2006.11.016]

110. Budney AJ, Fearer S, Walker DD, Stanger C, Thostenson J, Grabinski M, et al. An initial trial of a computerized behavioral intervention for cannabis use disorder. Drug Alcohol Depend 2011 May 1;115(1-2):74-79 [FREE Full text] [doi: 10.1016/j.drugalcdep.2010.10.014] [Medline: 21131143]

111. Gilbert P, Ciccarone D, Gansky SA, Bangsberg DR, Clanon K, McPhee SJ, et al. Interactive "Video Doctor" counseling reduces drug and sexual risk behaviors among HIV-positive patients in diverse outpatient settings. PLoS One 2008 Apr 23;3(4):e1988 [FREE Full text] [doi: 10.1371/journal.pone.0001988] [Medline: 18431475]

112. Kay-Lambkin FJ, Baker AL, Lewin TJ, Carr VJ. Computer-based psychological treatment for comorbid depression and problematic alcohol and/or cannabis use: a randomized controlled trial of clinical efficacy. Addiction 2009

Mar;104(3):378-388. [doi: 10.1111/j.1360-0443.2008.02444.x] [Medline: 19207345]

113. Lee CM, Neighbors C, Kilmer JR, Larimer ME. A brief, web-based personalized feedback selective intervention for college student marijuana use: a randomized clinical trial. Psychol Addict Behav 2010 Jun;24(2):265-273 [FREE Full text] [doi: 10.1037/a0018859] [Medline: 20565152]

114. Tossmann H, Jonas B, Tensil M, Lang P, Strüber E. A controlled trial of an internet-based intervention program for cannabis users. Cyberpsychol Behav Soc Netw 2011 Nov;14(11):673-679. [doi: 10.1089/cyber.2010.0506] [Medline: 21651419]

115. Williams C, Griffin KW, Macaulay AP, West TL, Gronewold E. Efficacy of a drug prevention CD-ROM intervention for adolescents. Subst Use Misuse 2005;40(6):869-878. [Medline: $\underline{15974146]}$

116. Bersamin M, Paschall MJ, Fearnow-Kenney M, Wyrick D. Effectiveness of a web-based alcohol-misuse and harm-prevention course among high- and low-risk students. J Am Coll Health 2007;55(4):247-254. [doi: 10.3200/JACH.55.4.247-254] [Medline: 17319331$]$

117. Bingham CR, Barretto AI, Walton MA, Bryant CM, Shope JT, Raghunathan TE. Efficacy of a web-based, tailored, alcohol prevention/intervention program for college students: 3-month follow-up. J Drug Educ 2011;41(4):405-430 [FREE Full text] [Medline: 22455103] 
118. Bishop D, Bryant KS, Giles SM, Hansen WB, Dusenbury L. Simplifying the delivery of a prevention program with web-based enhancements. J Prim Prev 2006 Jul;27(4):433-444. [doi: 10.1007/s10935-006-0042-z] [Medline: 16763766]

119. Croom K, Lewis D, Marchell T, Lesser ML, Reyna VF, Kubicki-Bedford L, et al. Impact of an online alcohol education course on behavior and harm for incoming first-year college students: short-term evaluation of a randomized trial. J Am Coll Health 2009;57(4):445-454. [doi: 10.3200/JACH.57.4.445-454] [Medline: 19114384 ]

120. Di Noia J, Schwinn TM, Dastur ZA, Schinke SP. The relative efficacy of pamphlets, CD-ROM, and the Internet for disseminating adolescent drug abuse prevention programs: an exploratory study. Prev Med 2003 Dec;37(6 Pt 1):646-653 [FREE Full text] [Medline: 14636798]

121. Epstein J, Collins K, Thomson N, Pancella T, Pauley D. The doubles: evaluation of a substance abuse education curriculum for elementary school students. J Child Adolesc Subst Abuse 2007;16(4):1-22. [doi: 10.1300/J029v16n04_01]

122. Hecht ML, Marsiglia FF, Elek E, Wagstaff DA, Kulis S, Dustman P, et al. Culturally grounded substance use prevention: an evaluation of the keepin' it R.E.A.L. curriculum. Prev Sci 2003 Dec;4(4):233-248. [Medline: 14598996]

123. Hustad JT, Barnett NP, Borsari B, Jackson KM. Web-based alcohol prevention for incoming college students: a randomized controlled trial. Addict Behav 2010 Mar;35(3):183-189 [FREE Full text] [doi: 10.1016/j.addbeh.2009.10.012] [Medline: 19900763]

124. Koning IM, van den Eijnden RJ, Verdurmen JE, Engels RC, Vollebergh WA. Long-term effects of a parent and student intervention on alcohol use in adolescents: a cluster randomized controlled trial. Am J Prev Med 2011 May;40(5):541-547. [doi: 10.1016/j.amepre.2010.12.030] [Medline: 21496753]

125. Kypri K, Saunders JB, Williams SM, McGee RO, Langley JD, Cashell-Smith ML, et al. Web-based screening and brief intervention for hazardous drinking: a double-blind randomized controlled trial. Addiction 2004 Nov;99(11):1410-1417. [doi: 10.1111/j.1360-0443.2004.00847.x] [Medline: 15500594]

126. Moore MJ, Soderquist J, Werch C. Feasibility and efficacy of a binge drinking prevention intervention for college students delivered via the Internet versus postal mail. J Am Coll Health 2005;54(1):38-44. [doi: 10.3200/JACH.54.1.38-44] [Medline: 16050327]

127. Neighbors C, Lewis MA, Atkins DC, Jensen MM, Walter T, Fossos N, et al. Efficacy of web-based personalized normative feedback: a two-year randomized controlled trial. J Consult Clin Psychol 2010 Dec;78(6):898-911 [FREE Full text] [doi: 10.1037/a0020766] [Medline: 20873892]

128. Rohrbach LA, Gunning M, Sun P, Sussman S. The Project Towards No Drug Abuse (TND) dissemination trial: implementation fidelity and immediate outcomes. Prev Sci 2010 Mar;11(1):77-88 [FREE Full text] [doi: 10.1007/s11121-009-0151-z] [Medline: 19757052$]$

129. Schinke SP, Cole KC, Fang L. Gender-specific intervention to reduce underage drinking among early adolescent girls: a test of a computer-mediated, mother-daughter program. J Stud Alcohol Drugs 2009 Jan;70(1):70-77 [FREE Full text] [Medline: 19118394]

130. Schinke SP, Schwinn TM, Di Noia J, Cole KC. Reducing the risks of alcohol use among urban youth: three-year effects of a computer-based intervention with and without parent involvement. J Stud Alcohol 2004 Jul;65(4):443-449 [FREE Full text] [Medline: $\underline{15376818}$ ]

131. Walters ST, Vader AM, Harris TR. A controlled trial of web-based feedback for heavy drinking college students. Prev Sci 2007 Mar;8(1):83-88. [doi: 10.1007/s11121-006-0059-9] [Medline: 17136461]

132. Warren J, Hecht M, Wagstaff D, Elek E, Ndiaye K, Dustman P, et al. Communicating prevention: the effects of the keepin' it REAL classroom videotapes and televised PSAs on middle-school students' substance use. J Appl Commun Res 2006 May;34(2):209-227. [doi: 10.1080/00909880600574153]

133. de Josselin de Jong JS, Candel M, Segaar D, Cremers H, de Vries H. Efficacy of a web-based computer-tailored smoking prevention intervention for Dutch adolescents: randomized controlled trial. J Med Internet Res 2014;16(3):e82 [FREE Full text] [doi: 10.2196/jmir.2469] [Medline: 24657434]

134. Doumas DM, Esp S, Turrisi R, Hausheer R, Cuffee C. A test of the efficacy of a brief, web-based personalized feedback intervention to reduce drinking among 9th grade students. Addict Behav 2014 Jan;39(1):231-238. [doi:

10.1016/j.addbeh.2013.10.011] [Medline: 24148137]

135. Doumas DM, Hausheer R, Esp S, Cuffee C. Reducing alcohol use among 9th grade students: 6 month outcomes of a brief, Web-based intervention. J Subst Abuse Treat 2014 Jul;47(1):102-105. [doi: 10.1016/j.jsat.2014.02.006] [Medline: 24666810]

136. Vogl LE, Newton NC, Champion KE, Teesson M. A universal harm-minimisation approach to preventing psychostimulant and cannabis use in adolescents: a cluster randomised controlled trial. Subst Abuse Treat Prev Policy 2014 Jun 18;9:24 [FREE Full text] [doi: 10.1186/1747-597X-9-24] [Medline: 24943829]

137. Malmberg M, Kleinjan M, Overbeek G, Vermulst A, Lammers J, Monshouwer K, et al. Substance use outcomes in the Healthy School and Drugs program: results from a latent growth curve approach. Addict Behav 2015 Mar;42:194-202. [doi: 10.1016/j.addbeh.2014.11.021] [Medline: 25481454]

138. Malmberg M, Kleinjan M, Overbeek G, Vermulst A, Monshouwer K, Lammers J, et al. Effectiveness of the 'Healthy School and Drugs' prevention programme on adolescents' substance use: a randomized clustered trial. Addiction 2014 Jun;109(6):1031-1040. [doi: 10.1111/add.12526] [Medline: 24612164] 
139. Velicer WF, Redding CA, Paiva AL, Mauriello LM, Blissmer B, Oatley K, et al. Multiple behavior interventions to prevent substance abuse and increase energy balance behaviors in middle school students. Transl Behav Med 2013 Mar;3(1):82-93 [FREE Full text] [doi: 10.1007/s13142-013-0197-0] [Medline: 23585821]

140. Bannink R, Broeren S, Joosten-van Zwanenburg E, van As E, van de Looij-Jansen P, Raat H. Effectiveness of a Web-based tailored intervention (E-health4Uth) and consultation to promote adolescents' health: randomized controlled trial. J Med Internet Res 2014 May 30;16(5):e143 [FREE Full text] [doi: 10.2196/jmir.3163] [Medline: 24878521]

141. Rundle-Thiele S, Schuster L, Dietrich T, Russell-Bennett R, Drennan J, Leo C, et al. Maintaining or changing a drinking behavior? GOKA's short-term outcomes. J Bus Res 2015 Oct;68(10):2155-2163. [doi: 10.1016/j.jbusres.2015.03.015]

142. Walton MA, Resko S, Barry KL, Chermack ST, Zucker RA, Zimmerman MA, et al. A randomized controlled trial testing the efficacy of a brief cannabis universal prevention program among adolescents in primary care. Addiction 2014 May;109(5):786-797 [FREE Full text] [doi: 10.1111/add.12469] [Medline: 24372937]

143. Bauman KE, LaPrelle J, Brown JD, Koch GG, Padgett CA. The influence of three mass media campaigns on variables related to adolescent cigarette smoking: results of a field experiment. Am J Public Health 1991 May;81(5):597-604. [Medline: 2014859]

144. Bauman KE, Brown JD, Bryan ES, Fisher LA, Padgett CA, Sweeney JM. Three mass media campaigns to prevent adolescent cigarette smoking. Prev Med 1988 Sep;17(5):510-530. [Medline: 3237655]

145. Bauman K, Padgett C, Koch G. A media-based campaign to encourage personal communication among adolescents about not smoking cigarettes: participation, selection and consequences. Health Educ Res 1989;4(1):35-44. [doi: 10.1093/her/4.1.35]

146. Brown JD, Bauman KE, Padgett CA. A validity problem in measuring exposure to mass media campaigns. Health Educ Q 1990;17(3):299-306. [Medline: 2228632]

147. L J, Bauman KE, Koch GG. High intercommunity variation in adolescent cigarette smoking in a 10-community field experiment. Eval Rev 2016 Jul 26;16(2):115-130. [doi: 10.1177/0193841x9201600201]

148. Fallin A, Neilands TB, Jordan JW, Hong JS, Ling PM. Wreaking "havoc" on smoking: social branding to reach young adult "partiers" in Oklahoma. Am J Prev Med 2015 Jan;48(1 Suppl 1):S78-S85 [FREE Full text] [doi: 10.1016/j.amepre.2014.09.008] [Medline: 25528713]

149. Flay BR, Miller TQ, Hedeker D, Siddiqui O, Britton CF, Brannon BR, et al. The television, school, and family smoking prevention and cessation project. VIII. Student outcomes and mediating variables. Prev Med 1995 Jan;24(1):29-40. [doi: 10.1006/pmed.1995.1005] [Medline: 7740012]

150. Flay BR, Brannon BR, Johnson CA, Hansen WB, Ulene AL, Whitney-Saltiel DA, et al. The television school and family smoking prevention and cessation project. 1. Theoretical basis and program development. Prev Med 1988 Sep;17(5):585-607. [Medline: 3237658 ]

151. Sussman S, Brannon BR, Flay BR, Gleason L, Senor S, Sobol DF, et al. The television, school and family smoking prevention/cessation project. II. Formative evaluation of television segments by teenagers and parents - implications for parental involvement in drug education. Health Educ Res 1986;1(3):185-194. [doi: 10.1093/her/1.3.185]

152. Sussman S, Dent CW, Brannon BR, Glowacz K, Gleason LR, Ullery S, et al. The television, school and family smoking prevention/cessation project. IV. Controlling for program success expectancies across experimental and control conditions. Addict Behav 1989;14(6):601-610. [Medline: 2618843]

153. Flynn BS, Worden JK, Secker-Walker RH, Badger GJ, Geller BM. Cigarette smoking prevention effects of mass media and school interventions targeted to gender and age groups. Journal of Health Education 2013 Mar 08;26(sup2):S45-S51. [doi: 10.1080/10556699.1995.10603147]

154. Flynn BS, Worden JK, Secker-Walker RH, Badger GJ, Geller BM, Costanza MC. Prevention of cigarette smoking through mass media intervention and school programs. Am J Public Health 1992 Jun;82(6):827-834. [Medline: 1585963]

155. Flynn BS, Worden JK, Secker-Walker RH, Pirie PL, Badger GJ, Carpenter JH. Long-term responses of higher and lower risk youths to smoking prevention interventions. Prev Med 1997;26(3):389-394. [doi: 10.1006/pmed.1997.0159] [Medline: 9144764]

156. Flynn BS, Worden JK, Secker-Walker RH, Pirie PL, Badger GJ, Carpenter JH, et al. Mass media and school interventions for cigarette smoking prevention: effects 2 years after completion. Am J Public Health 1994 Jul;84(7):1148-1150. [Medline: $\underline{8017542]}$

157. Secker-Walker RH, Worden JK, Holland RR, Flynn BS, Detsky AS. A mass media programme to prevent smoking among adolescents: costs and cost effectiveness. Tob Control 1997;6(3):207-212 [FREE Full text] [Medline: 9396105]

158. Worden JK, Flynn BS. Effective use of mass media to prevent cigarette smoking. J Public Health Manag Pract 2000 May;6(3):vii-viii. [Medline: 10848475]

159. Worden JK, Flynn BS, Geller BM, Chen M, Shelton LG, Secker-Walker RH, et al. Development of a smoking prevention mass media program using diagnostic and formative research. Prev Med 1988 Sep;17(5):531-558. [Medline: 3237656 ]

160. Worden JK, Flynn BS, Solomon LJ, Secker-Walker RH, Badger GJ, Carpenter JH. Using mass media to prevent cigarette smoking among adolescent girls. Health Educ Q 1996 Nov;23(4):453-468. [Medline: $\underline{\text { 8910024] }}$

161. Flynn BS, Worden JK, Bunn JY, Solomon LJ, Ashikaga T, Connolly SW, et al. Mass media interventions to reduce youth smoking prevalence. Am J Prev Med 2010 Jul;39(1):53-62 [FREE Full text] [doi: 10.1016/j.amepre.2010.03.008] [Medline: 20537841] 
162. Solomon LJ, Bunn JY, Flynn BS, Pirie PL, Worden JK, Ashikaga T. Mass media for smoking cessation in adolescents. Health Educ Behav 2009 Aug;36(4):642-659. [doi: 10.1177/1090198106298421] [Medline: 17602098]

163. Hafstad A, Aaro L. Activating interpersonal influence through provocative appeals: evaluation of a mass media-based antismoking campaign targeting adolescents. Health Commun 1997 Jul;9(3):253-272. [doi: 10.1207/s15327027hc0903_4]

164. Hafstad A. Provocative anti-smoking appeals in mass-media campaigns: an intervention study on adolescent smoking. Norway: Norwegian Women's Public Health Organisation; 1997.

165. Hafstad A, Aarø LE, Engeland A, Andersen A, Langmark F, Stray-Pedersen B. Provocative appeals in anti-smoking mass media campaigns targeting adolescents--the accumulated effect of multiple exposures. Health Educ Res 1997 Jun;12(2):227-236. [Medline: 10168574]

166. Hafstad A. Use of provocative emotional appeals in a mass media campaign designed to prevent smoking among adolescents. Eur J Public Health 1997 Jun 01;7(2):122-127. [doi: 10.1093/eurpub/7.2.122]

167. Longshore D, Ghosh-Dastidar B, Ellickson PL. National Youth Anti-Drug Media Campaign and school-based drug prevention: evidence for a synergistic effect in ALERT Plus. Addict Behav 2006 Mar;31(3):496-508. [doi: 10.1016/j.addbeh.2005.05.032] [Medline: 15979245]

168. Ellickson PL, McCaffrey DF, Ghosh-Dastidar B, Longshore DL. New inroads in preventing adolescent drug use: results from a large-scale trial of project ALERT in middle schools. Am J Public Health 2003 Nov;93(11):1830-1836. [Medline: 14600049]

169. Ghosh-Dastidar B, Longshore DL, Ellickson PL, McCaffrey DF. Modifying pro-drug risk factors in adolescents: results from project ALERT. Health Educ Behav 2004 Jun;31(3):318-334. [doi: 10.1177/1090198104263333] [Medline: 15155043]

170. Longshore D, Ellickson PL, McCaffrey DF, St Clair P. School-based drug prevention among at-risk adolescents: effects of ALERT plus. Health Educ Behav 2007 Aug;34(4):651-668. [doi: 10.1177/1090198106294895] [Medline: 17567823]

171. Worden J, Flynn B. Using television messages to prevent smoking among adolescents. University of Vermont: Office of Health Promotion Research and Biometry Facility, College of Medicine, Department of Mathematics (Statistics Program) College of Engineering and Mathematics; 1983 Presented at: American Public Health Association Annual Meeting; 1983; Dallas.

172. Stotts AL, Diclemente CC, Dolan-Mullen P. One-to-one: a motivational intervention for resistant pregnant smokers. Addict Behav 2002;27(2):275-292. [Medline: 11817768]

173. Rigotti NA, Park ER, Regan S, Chang Y, Perry K, Loudin B, et al. Efficacy of telephone counseling for pregnant smokers: a randomized controlled trial. Obstet Gynecol 2006 Jul;108(1):83-92. [doi: 10.1097/01.AOG.0000218100.05601.f8] [Medline: 16816060]

174. Peterson AV, Kealey KA, Mann SL, Marek PM, Ludman EJ, Liu J, et al. Group-randomized trial of a proactive, personalized telephone counseling intervention for adolescent smoking cessation. J Natl Cancer Inst 2009 Oct 21;101(20):1378-1392 [FREE Full text] [doi: 10.1093/jnci/djp317] [Medline: 19822836]

175. Severson HH, Peterson AL, Andrews JA, Gordon JS, Cigrang JA, Danaher BG, et al. Smokeless tobacco cessation in military personnel: a randomized controlled trial. Nicotine Tob Res 2009 Jun;11(6):730-738. [doi: 10.1093/ntr/ntp057] [Medline: $\underline{19395686]}$

176. Bastian LA, Fish LJ, Peterson BL, Biddle AK, Garst J, Lyna P, et al. Assessment of the impact of adjunctive proactive telephone counseling to promote smoking cessation among lung cancer patients' social networks. Am J Health Promot 2013;27(3):181-190. [doi: 10.4278/ajhp.101122-QUAN-387] [Medline: 23286595]

177. Jiménez-Muro A, Nerín I, Samper P, Marqueta A, Beamonte A, Gargallo P, et al. A proactive smoking cessation intervention in postpartum women. Midwifery 2013 Mar;29(3):240-245. [doi: 10.1016/j.midw.2012.01.003] [Medline: 22361008]

178. Woodruff SI, Conway TL, Edwards CC, Elliott SP, Crittenden J. Evaluation of an Internet virtual world chat room for adolescent smoking cessation. Addict Behav 2007 Sep;32(9):1769-1786. [doi: 10.1016/j.addbeh.2006.12.008] [Medline: 17250972]

179. Becker J, Haug S, Sullivan R, Schaub MP. Effectiveness of different Web-based interventions to prepare co-smokers of cigarettes and cannabis for double cessation: a three-arm randomized controlled trial. J Med Internet Res 2014 Dec 05;16(12):e273 [FREE Full text] [doi: 10.2196/jmir.3246] [Medline: 25486674]

180. Mason MJ, Campbell L, Way T, Keyser-Marcus L, Benotsch E, Mennis J, et al. Development and outcomes of a text messaging tobacco cessation intervention with urban adolescents. Subst Abus 2015;36(4):500-506. [doi: 10.1080/08897077.2014.987946] [Medline: 25551337]

181. Blankers M, Koeter MW, Schippers GM. Internet therapy versus internet self-help versus no treatment for problematic alcohol use: a randomized controlled trial. J Consult Clin Psychol 2011 Jun;79(3):330-341 [FREE Full text] [doi: 10.1037/a0023498] [Medline: 21534652]

182. Brown RL, Saunders LA, Bobula JA, Mundt MP, Koch PE. Randomized-controlled trial of a telephone and mail intervention for alcohol use disorders: three-month drinking outcomes. Alcohol Clin Exp Res 2007 Aug;31(8):1372-1379. [doi: 10.1111/j.1530-0277.2007.00430.x] [Medline: 17550366 ]

183. Borsari B, Short EE, Mastroleo NR, Hustad JTP, Tevyaw TO, Barnett NP, et al. Phone-delivered brief motivational interventions for mandated college students delivered during the summer months. J Subst Abuse Treat 2014 May;46(5):592-596 [FREE Full text] [doi: 10.1016/j.jsat.2014.01.001] [Medline: 24512944] 
184. LaChance H, Feldstein ES, Bryan AD, Hutchison KE. What makes group MET work? A randomized controlled trial of college student drinkers in mandated alcohol diversion. Psychol Addict Behav 2009 Dec;23(4):598-612 [FREE Full text] [doi: $10.1037 / \mathrm{a} 0016633$ ] [Medline: 20025366]

185. Wongpakaran T, Petcharaj K, Wongpakaran N, Sombatmai S, Boripuntakul T, Intarakamhaeng D, et al. The effect of telephone-based intervention (TBI) in alcohol abusers: a pilot study. J Med Assoc Thai 2011 Jul;94(7):849-856. [Medline: 21774293]

186. D'Amico EJ, Hunter SB, Miles JNV, Ewing BA, Osilla KC. A randomized controlled trial of a group motivational interviewing intervention for adolescents with a first time alcohol or drug offense. J Subst Abuse Treat 2013;45(5):400-408 [FREE Full text] [doi: 10.1016/j.jsat.2013.06.005] [Medline: 23891459]

187. D'Amico EJ, Houck JM, Hunter SB, Miles JNV, Osilla KC, Ewing BA. Group motivational interviewing for adolescents: change talk and alcohol and marijuana outcomes. J Consult Clin Psychol 2015 Feb;83(1):68-80 [FREE Full text] [doi: 10.1037/a0038155] [Medline: 25365779]

188. Nyamathi A, Shoptaw S, Cohen A, Greengold B, Nyamathi K, Marfisee M, et al. Effect of motivational interviewing on reduction of alcohol use. Drug Alcohol Depend 2010 Feb 01;107(1):23-30 [FREE Full text] [doi: 10.1016/j.drugalcdep.2009.08.021] [Medline: 19836904]

189. Nyamathi AM, Nandy K, Greengold B, Marfisee M, Khalilifard F, Cohen A, et al. Effectiveness of intervention on improvement of drug use among methadone maintained adults. J Addict Dis 2011 Jan;30(1):6-16 [FREE Full text] [doi: 10.1080/10550887.2010.531669] [Medline: 21218306]

190. Suffoletto B, Kristan J, Callaway C, Kim KH, Chung T, Monti PM, et al. A text message alcohol intervention for young adult emergency department patients: a randomized clinical trial. Ann Emerg Med 2014 Dec;64(6):664-72.e4 [FREE Full text] [doi: 10.1016/j.annemergmed.2014.06.010] [Medline: 25017822]

191. Suffoletto B, Kristan J, Chung T, Jeong K, Fabio A, Monti P, et al. An interactive text message intervention to reduce binge drinking in young adults: a randomized controlled trial with 9-Month Outcomes. PLoS One 2015;10(11):e0142877 [FREE Full text] [doi: 10.1371/journal.pone.0142877] [Medline: 26580802]

192. Gates PJ, Norberg MM, Copeland J, Digiusto E. Randomized controlled trial of a novel cannabis use intervention delivered by telephone. Addiction 2012 Dec;107(12):2149-2158. [doi: 10.1111/j.1360-0443.2012.03953.x] [Medline: 22632139]

193. Madigan K, Brennan D, Lawlor E, Turner N, Kinsella A, O'Connor JJ, et al. A multi-center, randomized controlled trial of a group psychological intervention for psychosis with comorbid cannabis dependence over the early course of illness. Schizophr Res 2013 Jan;143(1):138-142. [doi: 10.1016/j.schres.2012.10.018] [Medline: 23187069]

194. Stevens J, Hayes J, Pakalnis A. A randomized trial of telephone-based motivational interviewing for adolescent chronic headache with medication overuse. Cephalalgia 2014 May;34(6):446-454. [doi: 10.1177/0333102413515336] [Medline: 24322483]

195. Agyapong VIO, Ahern S, McLoughlin DM, Farren CK. Supportive text messaging for depression and comorbid alcohol use disorder: single-blind randomised trial. J Affect Disord 2012 Dec 10;141(2-3):168-176. [doi: 10.1016/j.jad.2012.02.040] [Medline: 22464008]

196. Weitzel JA, Bernhardt JM, Usdan S, Mays D, Glanz K. Using wireless handheld computers and tailored text messaging to reduce negative consequences of drinking alcohol. J Stud Alcohol Drugs 2007 Jul;68(4):534-537. [Medline: 17568957]

197. Suffoletto B, Callaway C, Kristan J, Kraemer K, Clark DB. Text-message-based drinking assessments and brief interventions for young adults discharged from the emergency department. Alcohol Clin Exp Res 2012 Mar;36(3):552-560. [doi: 10.1111/j.1530-0277.2011.01646.x] [Medline: 22168137]

198. Haug S, Schaub MP, Venzin V, Meyer C, John U, Gmel G. A pre-post study on the appropriateness and effectiveness of a Web- and text messaging-based intervention to reduce problem drinking in emerging adults. J Med Internet Res 2013;15(9):e196 [FREE Full text] [doi: 10.2196/jmir.2755] [Medline: 23999406]

199. Gajecki M, Berman AH, Sinadinovic K, Rosendahl I, Andersson C. Mobile phone brief intervention applications for risky alcohol use among university students: a randomized controlled study. Addict Sci Clin Pract 2014;9:11 [FREE Full text] [doi: 10.1186/1940-0640-9-11] [Medline: 24985342]

200. Gonzales R, Ang A, Murphy DA, Glik DC, Anglin MD. Substance use recovery outcomes among a cohort of youth participating in a mobile-based texting aftercare pilot program. J Subst Abuse Treat 2014 Jul;47(1):20-26 [FREE Full text] [doi: 10.1016/j.jsat.2014.01.010] [Medline: 24629885]

201. Gustafson DH, McTavish FM, Chih M, Atwood AK, Johnson RA, Boyle MG, et al. A smartphone application to support recovery from alcoholism: a randomized clinical trial. JAMA Psychiatry 2014 May;71(5):566-572 [FREE Full text] [doi: 10.1001/jamapsychiatry.2013.4642] [Medline: 24671165]

202. Lucht MJ, Hoffman L, Haug S, Meyer C, Pussehl D, Quellmalz A, et al. A surveillance tool using mobile phone short message service to reduce alcohol consumption among alcohol-dependent patients. Alcohol Clin Exp Res 2014 Jun;38(6):1728-1736. [doi: 10.1111/acer.12403] [Medline: 24730528]

203. Shrier LA, Rhoads A, Burke P, Walls C, Blood EA. Real-time, contextual intervention using mobile technology to reduce marijuana use among youth: a pilot study. Addict Behav 2014 Jan;39(1):173-180. [doi: 10.1016/j.addbeh.2013.09.028] [Medline: 24139665] 
204. Haug S, Lucht MJ, John U, Meyer C, Schaub MP. A pilot study on the feasibility and acceptability of a text message-based aftercare treatment programme among alcohol outpatients. Alcohol Alcohol 2015 Mar;50(2):188-194. [doi: 10.1093/alcalc/agu107] [Medline: 25600249]

205. Gonzalez VM, Dulin PL. Comparison of a smartphone app for alcohol use disorders with an internet-based intervention plus bibliotherapy: A pilot study. J Consult Clin Psychol 2015 Apr;83(2):335-345. [doi: 10.1037/a0038620] [Medline: 25622202]

206. Schwinn TM, Schinke SP, Di Noia J. Preventing drug abuse among adolescent girls: outcome data from an internet-based intervention. Prev Sci 2010 Mar;11(1):24-32 [FREE Full text] [doi: 10.1007/s11121-009-0146-9] [Medline: 19728091]

207. Wood S, Eckley L, Hughes K, Hardcastle K, Bellis M, Schrooten J, et al. Computer-based programmes for the prevention and management of illicit recreational drug use: a systematic review. Addict Behav 2014 Jan;39(1):30-38. [doi: 10.1016/j.addbeh.2013.09.010] [Medline: 24144590]

208. Hopson L, Wodarski J, Tang N. The effectiveness of electronic approaches to substance abuse prevention for adolescents. J Evid Inf Soc Work 2015;12(3):310-322. [Medline: 25661894]

209. Champion KE, Newton NC, Barrett EL, Teesson M. A systematic review of school-based alcohol and other drug prevention programs facilitated by computers or the internet. Drug Alcohol Rev 2013 Mar;32(2):115-123. [doi: 10.1111/j.1465-3362.2012.00517.x] [Medline: 23039085]

210. Newton NC, Andrews G, Champion KE, Teesson M. Universal Internet-based prevention for alcohol and cannabis use reduces truancy, psychological distress and moral disengagement: a cluster randomised controlled trial. Prev Med 2014 Aug;65:109-115. [doi: 10.1016/j.ypmed.2014.05.003] [Medline: 24823906]

211. Champion KE, Newton NC, Stapinski L, Slade T, Barrett EL, Teesson M. A cross-validation trial of an Internet-based prevention program for alcohol and cannabis: preliminary results from a cluster randomised controlled trial. Aust $\mathrm{N} Z \mathrm{~J}$ Psychiatry 2016 Jan;50(1):64-73. [doi: 10.1177/0004867415577435] [Medline: 25801662]

212. Champion KE, Newton NC, Stapinski LA, Teesson M. Effectiveness of a universal internet-based prevention program for ecstasy and new psychoactive substances: a cluster randomized controlled trial. Addiction 2016 Apr 13;111(8):1396-1405. [doi: 10.1111/add.13345]

213. Christoff AO, Boerngen-Lacerda R. Reducing substance involvement in college students: a three-arm parallel-group randomized controlled trial of a computer-based intervention. Addict Behav 2015 Jun;45:164-171. [doi: 10.1016/j.addbeh.2015.01.019] [Medline: 25679364]

214. Champion K, Newton N, Teesson M. Prevention of alcohol and other drug use and related harm in the digital age: what does the evidence tell us? Curr Opin Psychiatry 2016 Dec;29(4):242-249. [doi: 10.1097/YCO.0000000000000258] [Medline: 27153124]

215. Brinn MP, Carson KV, Esterman AJ, Chang AB, Smith BJ. Mass media interventions for preventing smoking in young people. Cochrane Database Syst Rev 2010 Nov 10(11):CD001006. [doi: 10.1002/14651858.CD001006.pub2] [Medline: 21069667]

216. Carson KV, Ameer F, Sayehmiri K, Hnin K, van Agteren JE, Sayehmiri F, et al. Mass media interventions for preventing smoking in young people. Cochrane Database Syst Rev 2017 Dec 02;6:CD001006. [doi: 10.1002/14651858.CD001006.pub3] [Medline: 28574573]

217. Eiser C, Eiser J, Pritchard M. Reactions to Drug Education: a comparison of two videos produced for schools. Br J Addict 1988 Aug;83(8):955-963. [doi: 10.1111/j.1360-0443.1988.tb01589.x]

218. Haug S, Paz Castro R, Meyer C, Filler A, Kowatsch T, Schaub M. A mobile phone-based life skills training program for substance use prevention among adolescents: pre-post study on the acceptance and potential effectiveness of the program, Ready4life. JMIR Mhealth Uhealth 2017 Oct 04;5(10):e143 [FREE Full text] [doi: 10.2196/mhealth.8474] [Medline: 28978498]

219. Deitz D, Cook R, Hendrickson A. Preventing prescription drug misuse: field test of the SmartRx Web program. Subst Use Misuse 2011;46(5):678-686. [doi: 10.3109/10826084.2010.528124] [Medline: 21043788]

220. Fang L, Schinke S, Cole K. Preventing substance use among early Asian-American adolescent girls: initial evaluation of a web-based, mother-daughter program. J Adolesc Health 2010 Nov;47(5):529-532 [FREE Full text] [doi: 10.1016/j.jadohealth.2010.03.011] [Medline: 20970090]

221. Terry-McElrath YM, Emery S, Szczypka G, Johnston LD. Potential exposure to anti-drug advertising and drug-related attitudes, beliefs, and behaviors among United States youth, 1995-2006. Addict Behav 2011;36(1-2):116-124 [FREE Full text] [doi: 10.1016/j.addbeh.2010.09.005] [Medline: 20961691]

222. Brannon BR, Dent CW, Flay BR, Smith G, Sussman S, Pentz MA, et al. The television, school, and family project. V. The impact of curriculum delivery format on program acceptance. Prev Med 1989 Jul;18(4):492-502. [Medline: 2798371]

223. Schinke S, Fang L, Cole K, Cohen-Cutler S. Preventing substance use among Black and Hispanic adolescent girls: results from a computer-delivered, mother-daughter intervention approach. Subst Use Misuse 2011;46(1):35-45 [FREE Full text] [doi: 10.3109/10826084.2011.521074] [Medline: 21190404]

224. Klisch Y, Bowling KG, Miller LM, Ramos MA. The impact of science education games on prescription drug abuse attitudes among teens: a case study. J Drug Educ 2013 Aug;43(3):255-275. [doi: 10.2190/DE.43.3.d] [Medline: 25445507] 
225. Schuman SH. Drug perception and the student-teacher gap. Reactions of 428 students and 72 teachers to an experimental trigger film on drugs. J Am Med Assoc 1971 Apr 26;216(4):659-663. [Medline: 4101684]

226. Flay BR. Mass media linkages with school-based programs for drug abuse prevention. J Sch Health 1986 Nov;56(9):402-406. [Medline: $\underline{3537525]}$

227. Schinke SP, Fang L, Cole KC. Computer-delivered, parent-involvement intervention to prevent substance use among adolescent girls. Prev Med 2009 Nov;49(5):429-435 [FREE Full text] [doi: 10.1016/j.ypmed.2009.08.001] [Medline: 19682490]

228. Hansen WB, Bishop DC, Bryant KS. Using online components to facilitate program implementation: impact of technological enhancements to all stars on ease and quality of program delivery. Prev Sci 2009 Mar;10(1):66-75. [doi: 10.1007/s11121-008-0118-5] [Medline: 19067165]

229. Andrews J, Gordon J, Hampson S, Gunn B, Christiansen S, Slovic P. Long-term efficacy of click city(r): tobacco: a school-based tobacco prevention program. Nicotine Tob Res 2014 Jan;16(1):33-41 [FREE Full text] [doi: 10.1093/ntr/ntt106] [Medline: 23884322]

230. Kinder BN. Attitudes toward alcohol and drug abuse. II. Experimental data, mass media research, and methodological considerations. International Journal of the Addictions 2009 Jul 03;10(6):1035-1054. [doi: 10.3109/10826087509028359]

231. Bandy P, President P. Recent literature on drug abuse prevention and mass media: focusing on youth, parents, women and the elderly. J Drug Educ 1995 Jan;13(3):255-271. [doi: 10.2190/2GXA-K970-5L68-RE14]

232. Johnson E, Delgado J. Reaching Hispanics with messages to prevent alcohol and other drug abuse. Public Health Rep 1989;104(6):588-594 [FREE Full text] [Medline: 2479957]

233. Jiang S, Wu L, Gao X. Beyond face-to-face individual counseling: a systematic review on alternative modes of motivational interviewing in substance abuse treatment and prevention. Addict Behav 2017 Dec;73:216-235. [doi: 10.1016/j.addbeh.2017.05.023] [Medline: 28554033]

234. Schinke SP, Fang L, Cole KC. Preventing substance use among adolescent girls: 1-year outcomes of a computerized, mother-daughter program. Addict Behav 2009 Dec;34(12):1060-1064 [FREE Full text] [doi: 10.1016/j.addbeh.2009.06.007] [Medline: 19632053]

235. Schwinn T, Schinke S, Hopkins J, Keller B, Liu X. An online drug abuse prevention program for adolescent girls: posttest and 1-year outcomes. J Youth Adolesc 2018 Dec;47(3):490-500. [doi: 10.1007/s10964-017-0714-4] [Medline: 28755247]

236. Moncher MS, Parms CA, Orlandi MA, Schinke SP, Miller SO, Palleja J, et al. Microcomputer-based approaches for preventing drug and alcohol abuse among adolescents from ethnic-racial minority backgrounds. Comput Human Behav 1989 Jan;5(2):79-93. [doi: 10.1016/0747-5632(89)90026-5]

237. Flay BR, Sobel JL. The role of mass media in preventing adolescent substance abuse. NIDA Res Monogr 1983;47:5-35. [Medline: 6419119]

238. Wallack L. Mass media campaigns: the odds against finding behavior change. Health Educ Q 2016 Sep 04;8(3):209-260. [doi: 10.1177/109019818100800302]

239. Wallack L. Mass media and drinking, smoking, and drug taking. In: Contemporary drug problems. United States: Elsevier; 1980:49-83.

240. Barcus F, Jankowski S. Drugs and the mass media. Ann Am Acad Polit Soc Sci 2016 Sep 08;417(1):86-100. [doi: 10.1177/000271627541700109]

241. Andrews J, Gordon J, Hampson S, Christiansen S, Gunn B, Slovic P, et al. Short-term efficacy of Click City®: Tobacco: changing etiological mechanisms related to the onset of tobacco use. Prev Sci 2011 Mar;12(1):89-102 [FREE Full text] [doi: 10.1007/s11121-010-0192-3] [Medline: 21286810]

242. Kazemi DM, Borsari B, Levine MJ, Li S, Lamberson KA, Matta LA. A systematic review of the mHealth interventions to prevent alcohol and substance abuse. J Health Commun 2017 May;22(5):413-432. [doi: 10.1080/10810730.2017.1303556] [Medline: 28394729]

243. The Evolution of Media. In: Understanding Media and Culture: An Introduction to Mass Communication. United States: University of Minnesota Libraries Publishing edition; 2016:22-21.

244. Marsch L, Bickel W, Badger G. Applying computer technology to substance abuse prevention science: results of a preliminary examination. J Child Adolesc Subst Abuse 2007 Mar 06;16(2):69-94. [doi: 10.1300/J029v16n02 04]

245. U.S. Department of Health and Human Services. HHS.GOV/OPIOIDS. 2018. What is the U.S. Opioid Epidemic? URL: https://www.hhs.gov/opioids/about-the-epidemic/index.html [accessed 2018-07-20] [WebCite Cache ID 713YWM9Mh]

\section{Abbreviations}

CHIT: consumer health information technology

mHealth: mobile health

NPS: new psychoactive substances

RCT: randomized controlled trials

STDs: sexually transmitted diseases

WHO: World Health Organization 


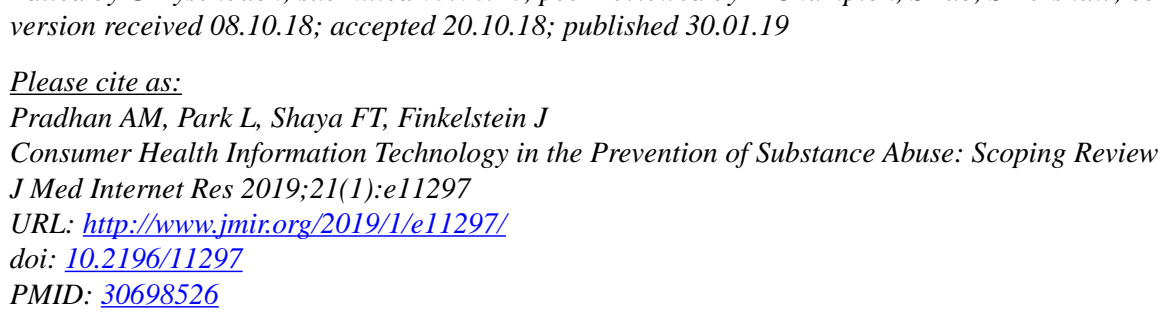

(C)Apoorva Milind Pradhan, Leah Park, Fadia T Shaya, Joseph Finkelstein. Originally published in the Journal of Medical Internet Research (http://www.jmir.org), 30.01.2019. This is an open-access article distributed under the terms of the Creative Commons Attribution License (https://creativecommons.org/licenses/by/4.0/), which permits unrestricted use, distribution, and reproduction in any medium, provided the original work, first published in the Journal of Medical Internet Research, is properly cited. The complete bibliographic information, a link to the original publication on http://www.jmir.org/, as well as this copyright and license information must be included. 